\title{
Los extranjeros en el Caribe hispano en vísperas de la Independencia: enemigos, revolucionarios, héroes errantes y hombres de buena fe
}

\author{
Frédérique LANGUE \\ Directrice de recherche \\ Mascipo-CNRS \\ École des Hautes Études en Sciences Sociales \\ 190-198 avenue de France \\ 75244 Paris cedex 13, Francia \\ flangue@ehess.fr
}

Fecha de recepción: 03/06/2011

Fecha de aceptación: 15/12/2011

\section{RESUMEN}

En la perspectiva de la historia de América, y en el contexto más amplio de la historia atlántica, el estudio de los procesos políticos y sociales que antecedieron las revoluciones de Independencia cobra especial significado en el tiempo largo. En un espacio muy concurrido -el "Mediterráneo del Caribe"- la circulación -oficial o no- de los hombres y de las ideas en una coyuntura de reformulación y luego de quiebra del pacto imperial, merece un análisis más profundo de sus distintos actores sociales y especialmente de sus márgenes. En ese crisol de intereses imperiales tanto mercantiles como estratégicos, la presencia de los extranjeros, considerados como portadores de ideas perniciosas y de revoluciones políticas, despertó en efecto no pocos temores y hasta miedos que la historia de las representaciones y sensibilidades nos permite evidenciar, analizar, y también relativizar en este ensayo.

Palabras clave: Caribe, Venezuela, Independencia, revoluciones, imperios, comercio, extranjeros, ideas.

\section{Foreigners in the Spanish Caribbean World on the eve of the Independence: Enemies, revolutionaries, wandering heroes and men of good faith}

\begin{abstract}
From the Spanish American historical point of view, and in the broader context of the Atlantic history, the study of political and social processes that preceded the Independence revolutions is quite significant in the long run. In a crowded space -the "Mediterranean (side) of the Caribbean"- the circulation -whether official or not- of men and ideas in a period of reformulation and breaking of imperial links, deserves a more in-depth analysis of social actors and especially of the diverse fringes of colonial society. In this melting pot of imperial interests (mercantile and strategic as well), the presence of foreigners, considered as propagandists of pernicious ideas and political revolutions, aroused fears that the history of representations and sensibilities allows us to see more clearly, to analyze, and to relativize in this essay.
\end{abstract}

Keywords: Caribbean, Venezuela, Independence, Revolutions, Empires, Trade, Foreigners, Ideas. 


\section{INTRODUCCIÓN}

Los procesos políticos y sociales que llevaron a la consumación de las revoluciones de Independencia americanas, por más que se estén celebrando y conmemorando en la actualidad como puntos de partida insoslayables de identidades nacionales -en cuanto rupturas originarias- no pueden considerarse haciendo caso omiso o tabula rasa de un contexto de larga duración que influyó de forma duradera en la conformación de los idearios políticos de las jóvenes naciones y de los imaginarios políticos afines. Resulta imprescindible considerar la llamada "revolución atlántica" -en las palabras de los precursores J. Godechot y R. Palmer, o sea unas cuantas décadas antes de que se iniciara la moda historiográfica de la "historia atlántica"-, con la difusión no sólo de las "perniciosas" ideas revolucionarias (fundamentalmente francesas) y también de los ejemplos concretos y hasta ejemplificados de la aplicación de las mismas (Haití y Santo Domingo, las rebeliones venezolanas, etc.). También habría que tener en cuenta, dentro de los catalizadores del estallido emancipador -y luego independentista- las reformas que los Borbones iniciaron en lo institucional y en lo político para América en el último tercio del siglo XVIII, en preludio a las revoluciones políticas. No fue en efecto la Independencia política la primera meta anhelada por sus actores políticos y especialmente las élites locales, sino alguna que otra forma de autonomía, fundamentalmente en lo económico y fiscal, respecto a la metrópoli ${ }^{1}$.

Uno de los aspectos más subrayados para las postrimerías de ese período descansa en efecto en la reformulación del pacto imperial y plantea por lo tanto las modalidades de las relaciones de la metrópoli con sus vasallos de ultramar. El Caribe experimentó cambios significativos en lo que a economía de plantación y sociedad esclavista se refiere, convirtiéndose en un caleidoscopio en los términos de F. Knight, y por más que la experiencia común a la esclavitud y a la sociedad de plantación hayan "opacado" unos cambios tan drásticos en la estructura social ${ }^{2}$. En vísperas de la Independencia de Iberoamérica, la relación con los residentes o súbditos extranjeros, tradicionalmente objeto de preocupación para la Corona (como lo demuestra la larga trayectoria de las llamadas cartas de naturaleza en Indias) cobra especial sentido, y más todavía en una coyuntura de intensa circulación de los hombres y de las ideas. El contexto europeo de "monarquías compuestas" (J. Elliott) con visos imperiales también se añade a la larga lista de los factores explicativos del estallido revolucionario y antes, del frágil equilibrio que se dio en determinados espacios clave para la geopolítica de los imperios. Incide sobremanera en la naturaleza y las modalidades de la presencia extranjera en el Caribe, en un contexto de guerras y cambiantes alianzas entre potencias europeas instaladas en sus recintos insulares (España, Inglaterra, Francia, Países Bajos), siendo la guerra comercial una constante que se ha ido amplificando a lo

\footnotetext{
1 Godechot, Jacques, PAlmer, Robert R.: «Le problème de l'Atlantique du XVIIIe au XXe siècle», en Relazioni del X Congreso Internazionale di Scienze Storiche, Roma, 1955, vol. 5, Storia contemporanea, Firenze, Sansoni, 1955 .

2 Guerra, François-Xavier: «La ruptura originaria: mutaciones, debates y mitos de la Independencia», en Álvarez Cuartero, Izaskun y SÁnchez Gómez, Julio (eds.): Visiones y revisiones de la Independencia Americana, Salamanca, Ediciones Universidad, 2003, pp. 89-110. KNIGHT, Franklin W.: «El Caribe en la época de la Ilustración», en Piqueras, José A. (ed.): Las Antillas en la era de las Luces y la revolución, Madrid, Siglo XXI, 2005, p. 11.
} 
largo del siglo XVIII (corso incluido) hasta desembocar en una "lucha de imperios" $\mathrm{y}$ en las consabidas crisis americanas. Mientras tanto, no son pocos los comerciantes, especialmente gaditanos, que recorren por ejemplo la ruta Cádiz-Cartagena vía La Habana, quienes piden moratorias por haber perdido sus embarcaciones, apresadas por las "armas anglicantes".

El "Mediterráneo del Caribe", tal como lo caracterizó F. Braudel, desempeñó por lo tanto un papel nuclear en la ideación de estrategias geopolíticas en la época moderna, desde la empresa descubridora en el siglo XVI y el afianzamiento de la colonización ibérica de América, y, por ende, en la conformación de un imaginario nutrido de crónicas, informes de arbitristas o representantes de la Monarquía ibérica, y, obviamente, su contrapartida al final del período colonial. La mayor preocupación de la Corona en ese momento radica en la difusión de impresos, folletos, libelos, y otros pasquines así como de las noticias (que transitaron desde las islas bajo soberanía francesa o también salieron en fardos embarcados en Cádiz) y de los consiguientes "malos ejemplos".

Nos interesa profundizar aquí la aprensión que tuvieron los actores políticos y sociales de estos elementos alógenos, ya fuesen extranjeros o bien forasteros, desde la perspectiva de las representaciones y sensibilidades, teniendo en cuenta la "recepción" de los acontecimientos en cuanto fragmentos de realidad percibida o vivida y en todo caso compartida. Son las guerras y revoluciones, o los aconteceres de "escasa intensidad", anunciados o repentinos, reales o imaginados que hacen que la figura del extranjero se convierta en una amenaza más o menos concreta y temible que aparece a todas luces en los relatos oficiales o no y hasta en los rumores del tiempo. En este sentido, y más allá de su temporalidad propia, el acontecimiento o suceso no deja de ser la piedra angular del relato, se plasma en el lenguaje, se inserta en un contexto que contempla no sólo lo acaecido sino lo que le antecede y la manera de cómo se enfoca hasta insertarse en una memoria, individual y colectiva a la vez, que se ubica en el campo de las emociones y le confiere sentido, a veces a posteriori ${ }^{4}$.

Por eso mismo, habida cuenta de estas múltiples interacciones y de la conjunción de alteridades que propicia, este temor y hasta el miedo al otro que encierra cobra sin lugar a duda especial sentido por lo que a representaciones sociales y políticas se re-

\footnotetext{
3 Adelman, Jeremy: Sovereignty and Revolution in the Iberian Atlantic, Oxford/Princeton, Princeton University Press, 2006, p. 9. Sobre redefinición de las relaciones imperiales, Cf. Morelli, Federica: «La redefinición de las relaciones imperiales: en torno a la relación reformas dieciochescas/independencia en América», Nuevo Mundo Mundos Nuevos, Debates, n. 8 (2008): http://nuevomundo.revues.org/32942. Véase para una reubicación dentro de una problemática euro-americana, Сhust, Manuel y Frasquet, Ivana: Las independencias en América, Madrid, Los Libros de la Catarata, 2009, y Frasquet, Ivana y Slemian, Andréa (eds.): De las independencias iberoamericanas a los estados nacionales (1810-1850): 200 años de historia, Madrid, Ahila-Iberoamericana Vervuert, 2009 , p. 17. Elliott, John H.: España, Europa y el Mundo de Ultramar (1500-1800), Madrid, Taurus, 2010, p. 29. Archivo General de Indias (en adelante AGI), Indiferente, 801: Joseph Burlando, vecino y del comercio de la ciudad de Cádiz, al Consejo de Indias, 17 de julio de 1770 .

4 Sobre la definición del acontecimiento o acontecer histórico y la categorización del mismo, remitimos al monográfico de la revista Terrain, 38 (mars 2002), «Qu'est-ce qu’un événement?» y especialmente el artículo de FARGe, Arlette: «Penser et définir l'événement en histoire. Approche des situations et des acteurs sociaux». Disponible en: http://terrain.revues.org/index3902.html y http://terrain.revues.org/index1929.html (artículo citado). Véase también LABORIE, Pierre: L'opinion française sous Vichy. Les Français et la crise d'identité nationale, 19361944, París, Le Seuil, 2001, prólogo.
} 
fiere, se afianza en el imaginario de unas élites locales seguidoras del modelo cultural hispánico y de una monarquía ibérica encarnada en la muy eficiente figura de los intendentes, en cuya función y cargo se unen tanto lo financiero como lo militar. En esa percepción y del silencio o, al contrario, de la memoria que de ella se deriva, imperan además diferencias fundamentales de estatuto entre los extranjeros representantes oficiales de su "nación" y los individuos, emigrantes o viajeros aislados y aventureros, que recorren el Caribe hispano insular y su parte de Tierra Firme (Venezuela) en la "era de la revoluciones" ejemplificada por E. Hobsbawn .

\section{EL CARIBE HISPANO, CRISOL DE INTERESES IMPERIALES}

Queda por subrayar una especificidad de la región caribeña, dentro de la lógica imperial, que no dejó de influir precisamente en la cronología de las independencias y en la formación de los estados-naciones dentro del proceso de descolonización de América. La formación de los Estados Unidos de América a partir de la década de los sesenta (1776-1783) y más todavía los acontecimientos de los ochenta y noventa (Revolución francesa en sus distintas etapas, de 1789 en adelante), son parte de este proceso que modifica radicalmente las modalidades de la presencia imperial y por lo tanto las apuestas de las mencionadas naciones en el Caribe. Un hito al respecto lo constituye el "incendio" revolucionario de la floreciente colonia francesa de Santo Domingo, de 1791 a 1804, que dejó no pocas huellas en los imaginarios locales. Dos son en efecto las excepciones que cundieron en el mundo hispánico en las primeras décadas del siglo XIX, Cuba y Puerto Rico, que no van a lograr su independencia sino hasta el año 1898. Esta "excepción americana", ejemplificada en la obra del criollo "sacarócrata" Francisco Arango y Parreño, se originó tanto en la nutrida presencia de partidarios del sistema colonial -tales como los numerosos emigrantes que arribaron a Cuba en la segunda mitad del siglo XVIII, los refugiados (unos 40.000 individuos) del continente sublevado instalados en Cuba, o los colonos de Santo Domingo que se establecieron en la parte oriental de Cuba, como en los temores manifestados no sólo por las élites blancas criollas o "españolas" sino también por la población blanca en general ante los "estragos" de Saint-Domingue/Haití (éstos desembocaron en la abolición de la esclavitud e independencia en lo político) ${ }^{6}$.

\footnotetext{
${ }^{5}$ Un ejemplo de este tipo de aproximación en Langue, Frédérique: «Bolívar, Mantuano y Héroe. Representaciones y sensibilidades ante el mito republicano», Nuevo Mundo, Mundos Nuevos, 8 (2008): http://nuevomundo.revues. org/14632 Hobsbawn, Eric: L'Ére des révolutions: 1789-1848, París, Editions Complexe, 1988 (The Age of Revolution, 1962). No incluimos las costas novohispanas en este estudio por resultar distintas las repercusiones y la aprensión de los "horrores de Haití". Sin embargo, ya realizamos una primera aproximación al tema de la presencia extranjera en Nueva España en «Los franceses en Nueva España a fines del siglo XVIII, Notas sobre un estado de opinión», Anuario de Estudios Americanos, vol. XLVI (1989), pp. 219-241. Este estudio forma parte de una investigación mucho más extensa acerca de la circulación extranjera en el arco caribeño que va de Cuba a la costa venezolana.

${ }^{6}$ Balboa, Imilcy y Piqueras, José Antonio (eds.): La excepción americana, Valencia, Centro Francisco Tomás y Valiente/UNED Alzira-Valencia, 2006. Opatrny, Josef: «El contexto histórico de la búsqueda de identidad de Cuba en José Antonio Saco», en Paz Sánchez, Manuel de y Naranjo Orovio, Consuelo (coords.): Identidades e independencias. División e integración en las dos orillas, 1808-2008, Santa Cruz de Tenerife, Ediciones IDEA, 2009, pp. 24-29. Piqueras Arenas, José Antonio: «Leales en época de insurrección. La élite criolla cubana entre 1810 y 1814», en Álvarez Cuartero, Izaskun y Sánchez Gómez, Julio (eds.): Visiones y revisiones de la Independencia
} 
Hasta se puede hablar de un miedo generalizado ante la población de color y el espíritu díscolo y rebelde de los esclavos, de los que se temía que siguieran el modelo haitiano y repitieran los "horrores revolucionarios" en perjuicio de una economía de plantación y de una sociedad de las más prósperas. Recordemos en efecto que Haití fue el segundo Estado libre de las Américas (1804), poniendo de esta forma término a la cohesión del imperio británico, y la primera sociedad esclavista de la región en acabar con la esclavitud. Inició además la desintegración de esta institución en el mundo americano puesto que en 1807 se decreta la abolición del comercio transatlántico de esclavos por los ingleses, aunque se considera que el referido comercio siguió hasta los años 1870. El Caribe fue así el primer escenario de la abolición gradual de la esclavitud, y el último -en 1792 y 1888 respectivamente-, y por lo tanto un espacio de lo más propicio a la coexistencia, si no a la conjunción de unas comunidades foráneas y de la población de color/de castas?

Otros factores y aconteceres de variadas escalas también nutrieron estos temores, más allá de la cronología aplicada comúnmente al estallido revolucionario y a sus antecedentes. Tal fue el caso del ya mencionado debilitamiento de las colonias inglesas que tuvieron que renunciar in fine a la esclavitud, o la concesión por España de la libertad de comercio (1778 y 1789). También conviene resaltar en lo económico la apertura del mercado norteamericano, amén del relativo aislamiento de las islas en un escenario compartido oficialmente o no (corsarios) con otras potencias, circunstancia que dificultó sobremanera y hasta impidió una actuación firme y unitaria en lo militar de parte de las fuerzas independentistas ante unas flotas y un ejército españoles considerables (30.000 soldados). Ahí radica además la principal diferencia con lo que sucedió en Tierra Firme. Esta excepción, así como la reformulación de las redes comerciales y económicas caribeñas, se dieron en un contexto de revolución industrial y también agrícola, y especialmente azucarera, bajo el impulso en gran parte de los Estados Unidos de América. Hay que recordar en ese aspecto el hecho de que adquirieron el territorio francés de Luisiana en 1803, y el territorio español de Florida en 1819.

Estas reconfiguraciones políticas y estratégicas no dejan por lo tanto de tener repercusiones en la presencia, o, al contrario, en la ausencia cíclica o puntual de determinadas naciones en las referidas islas. Asimismo influyen en la conformación y el desarrollo de redes propias de los distintos imperios y transnacionales a la vez, siendo la circulación de élites mercantiles y hasta de "clanes financieros" un tema clave aunque todavía escasamente trillado de las llamadas "historias cruzadas" o connected histories e incluso de la "historia atlántica". También conviene tener en cuenta, y más todavía en la perspectiva de la historia de las representaciones, la naturaleza de los miedos que fueron cundiendo a raíz de las turbulencias haitianas y de las "revoluciones atlánticas" en general, y hasta el "miedo interesado" que surgió y se desarrolló

\footnotetext{
Americana, Salamanca, Ediciones Universidad, 2003, p. 188.

7 González-Ripoll, María Dolores: «Desde Cuba, antes y después de Haití: pragmatismo y dilación en el pensamiento de Francisco Arango sobre la esclavitud», en GonzÁlez-Ripoll, Ma Dolores, Naranjo Orovio, C., Ferrer, A., García, G. y Opatrny, J.: El rumor de Haití en Cuba: temor, raza y rebeldía, 1789-1844, Madrid, CSIC, 2004, p. 17.
} 
dentro de la población blanca de determinados reductos insulares caribeños mientras en la vertiente continental y especialmente en las nacientes Repúblicas seguía la disyuntiva y por consiguiente el acérrimo debate acerca de la libertad y de la igualdad de los (nuevos) ciudadanos ${ }^{8}$.

Lugar tradicionalmente de rivalidades comerciales, tanto en el trastornado orden colonial o mejor dicho oficial (vinculado en este caso con la problemática de las alianzas de turno en los sucesivos contextos bélicos) como oficioso (corso, comercio "furtivo"), el Mediterráneo del Caribe de acuerdo con la expresión acuñada por F. Braudel se señala tempranamente como el punto de llegada de la flota, y por lo tanto como el lugar clave de los intereses económicos y militares de la monarquía ibérica, de sus vasallos y agentes. La presencia de otros imperios, ya sea en su vertiente mercantil o bien mediante sus corsarios, la realidad de su afianzamiento in situ mediante ciertas islas (caso de Curazao), justifican la mayor preocupación ostentada por el gobierno a la hora de controlar la presencia extranjera en América, especialmente mediante la otorgación de cartas de naturaleza en Indias (del jenízaro al residente en Indias) o de concesiones. Hay que recordar que, pese a la interrupción del proceso migratorio y de las primeras oleadas -cuyos integrantes, franceses, flamencos e italianos llegados a lo largo del siglo XVI se habían "criollizado" hasta en el apellido- de los siglos anteriores, ciertos puertos de arribo, además de ser lugares clave del comercio negrero, desempeñaron un papel especial: así Cartagena fue uno de los primeros lugares de América donde se hicieron composiciones con extranjeros a partir de finales del siglo XVI, y siguió siendo "puerto obligado para todo aquel que quisiera introducirse de forma subrepticia en el Continente Sur". . Otro tanto puede decirse del aspecto militar, o sea de la conservación y defensa de los territorios del espacio gran caribeño tal como se evidencia a través de las costosas plazas militares y fortificaciones, de las Floridas hasta Trinidad pasando por el Golfo de México, el eje Veracruz-La Habana, Puerto Rico y Santo Domingo, las "islas extranjeras de Barlovento y Sotavento", y Tierra Firme, con La Guaira y Cartagena. Tanto los designios expansionistas norteamericanos como las ambiciones inglesas constituyen elementos claves de la política de los Borbones en dicha región. Hay que recordar sin embargo que seguía vigente, en el caso español, la antigua prohibición del año 1718 de comerciar con Indias con buques de fabricación extranjera, salvo correspondiente habilitación: todavía en 1788, el comandante del resguardo de Caracas llega a apresar y decomisar un bergantín francés en la costa de Puerto Rico ${ }^{10}$.

\footnotetext{
8 NARANJo Orovio, Consuelo: «La amenaza haitiana, un miedo interesado: poder y fomento de la población blanca en Cuba», Idem, pp. 83 ss. Helg, Aline: Liberty and Equality in Caribbean Colombia 1770-1835, Chapell Hill-London, The University of North Carolina Press, 2004, pp. 243-253. Yun Casalilla, Bartolomé (dir.): Las redes del imperio. Élites sociales en la articulación de la monarquía hispánica, 1492-1714, Madrid, Marcial Pons Historia-Universidad Pablo de Olavide, 2009, passim. Véase el balance bibliográfico de Morelli, Federica, y Gómez, Alejandro E.: «La nueva Historia Atlántica: un asunto de escalas», Nuevo Mundo, Mundos Nuevos, 6 (2006), http:// nuevomundo.revues.org/2102

9 Vila Vilar, Enriqueta: Aspectos sociales en América colonial. De extranjeros, contrabando y esclavos, Bogotá, Instituto Caro y Cuervo-Universidad de Bogotá Jorge Tadeo Lozano, 2001, pp. 4-5.

10 Grafenstein, Johanna von: «Políticas de defensa de la España en el Gran Caribe y el papel del virreinato novohispano», en Grafenstern, Johanna von: El Caribe en los intereses imperiales 1750-1815, México, Instituto Mora, 2000, pp. 46 y ss. AGI, Caracas, 354: expediente sobre aprobación del comiso del bergantín francés El
} 
En cuanto a las nacionalidades o mejor dicho las "naciones" presentes de forma regular u ocasionalmente más continua e incisiva, los holandeses fueron de los negociantes que se beneficiaron de un acceso directo a los puertos de América española: aprovecharon las rutas directas, sin pasar por Cádiz. Portobelo, Cartagena de Indias y especialmente Caracas fueron algunos de estos destinos -junto con Buenos Airesque fueron aprovechados desde Amsterdam para traer a Europa productos coloniales de alta demanda. Estas rutas aceptadas por las autoridades españolas, lo mismo que el paso de los mercaderes extranjeros por Cádiz, se "complementaron" de cierta forma con el comercio ilícito. Sin embargo, estas circunstancias - unidas a la conformación de redes en parte familiares, de comunidades o colonias de mercaderes-favorecieron la integración económica y social de los mercaderes holandeses y flamencos en los referidos puertos de ultramar, contrarrestando las políticas agresivas de los ingleses y de los franceses. Está comprobado que la West India Company sólo pudo "sobrevivir" - en palabras de Crespo Solana- gracias a esa combinación de comercio legal (que seguía la flota de los galeones) y de contrabando (smuggling) llevada a la práctica desde Curazao, apoyándose además en las élites locales o en la misma administración de Venezuela (La Guaira, Maracaibo, Cumaná) o de Nueva Granada (Cartagena). Hasta se dieron casos de oficiales o empleados de la Real Hacienda de Cumaná y Caracas o del resguardo de costas, quienes, después de decomisar efectos extranjeros, los trasladaron por cuenta propia a Caracas (1797). A partir de 1795, la Junta Superior de Real Hacienda menciona reiteradamente un "grueso contrabando de géneros extranjeros y tabaco de Virginia y que los introductores pretendían internarlo a esta provincia [de Caracas]". En la misma costa de Barlovento, a un "visitador de resguardo" le corresponde aprehender "efectos de contrabando". Y por Maracaibo, son individuos de varias castas quienes se dedican constantemente a vender efectos extranjeros, del dueño de la balandra utilizada al efecto a las esclavas que llevan las canastas ${ }^{11}$.

Los estudios de Ramón Aizpurua sobre Curazao apuntan claramente a la existencia de esas redes "de comercio furtivo" o "ilí́cito", con la costa de Caracas (Cumaná, Margarita), de forma directa (mediante trato directo aunque prohibido entre extranjeros, curazoleños especialmente judíos, franceses, ingleses, y españoles), o indirecta (fraude, hurto), mediante familias de mercaderes o insertándose también en las economías locales de las distintas naciones e incluso en "redes internas". Del tabaco a

Gallardo apresado en la costa de Puerto Rico por el comandante del resguardo de Caracas, Don Antonio de Careaga. El Intendente de Caracas a Don Diego Gardoqui, 27 de marzo de 1792.

${ }_{11}$ Crespo Solana, Ana: «Dutch Mercantile Networks and the Trade with the Hispanic Port Cities in the Atlantic (1648-1778)», en Bottcher, Nikolaus, Hausberger, Bernd e Ibarra, Antonio (coords.): Redes y negocios globales en el mundo ibérico, siglos XVI-XVIII, Iberoamericana-Vervuert-El Colegio de México, 2011, p. 111. AGI, Caracas, 361: la Junta superior de Real Hacienda a la Corona, Caracas, 22 de abril de 1795. AGI, Caracas, 364: índice alfabético de los expedientes del negociado de Caracas desde 1760 a 180..." (1805: sobre aprensión de varios efectos de contrabando hecha en el sitio de Picure por D. Miguel Ruiz, visitador del resguardo de la costa de Barlovento). AGI, Caracas, 267: en cumplimiento de la Real Orden del 8 de septiembre de 1777, el Gobernador de Maracaibo da cuenta de varios comisos, entre ellos de "varios efectos aprehendidos por los guardas de la Compañía Guipuzcoana, Don Rafael Delgado y Francisco Albuquerque, teniente y alférez del regimiento fijo de Cartagena en la plazuela de S. Francisco en Maracaibo, en la casa de habitación de D. Joseph Gerónimo Tovar y en la balandra Nuestra Señora del Pino, de Don Domingo Alvarez". 
las mulas, pasando por las especies, los tejidos más diversos y las pieles, los metales (cobre o estaño), muy variados resultaron ser los productos comercializados de esta forma. Las desavenencias dentro de las élites locales también desempeñaron un papel decisivo a la hora de configurar estas redes transatlánticas y caribeñas si consideramos el controvertido monopolio de los comerciantes vascos de la Compañía Guipuzcoana. En el caso de los holandeses, tampoco hay que descartar las actuaciones violentas, o mejor dicho la "extracción" realizada con frecuencia por las balandras capitaneadas por "capitanes holandeses" o "capitanes del tráfico de Curazao" en perjuicio de las embarcaciones "asaltadas" por los anteriores que cubrían la ruta hacia La Guaira (procedentes de otros puertos menores como Higuerote u Ocumare de la Costa) y luego rumbo a otros puertos del Caribe cargadas con cacao y de la Real Hacienda despojada de los correspondientes derechos.

A veces, dejaban "en cambio ciertos géneros", decomisados con igual frecuencia por los oficiales reales, en perjuicio de los dueños del cacao y de los patrones y tripulación de las embarcaciones "insultadas por los holandeses". En 1763, se reporta el caso de Juan Cubas, quien conducía cacao de Ocumare a La Guaira, víctima de la "sustracción de cacao y cambio de géneros que se hizo por los Holandeses de una balandra de Curazao, su capitán Felipe Cristiano, el mercader (un judío llamado Michi), y el dueño del barco nombrado Abraham". En el mismo año de 1763, una "extracción violenta de noventa fanegas de cacao" (pero podía pasar de las 400 fanegas) la ejecutó en la lancha de Clemente Cordero que iba de Higuerote a La Guaira, el capitán de la goleta holandesa "Antonio Barviquejo, negro de Curazao, dándole a su arbitrio diferentes géneros".

De las notorias y "grandes extracciones que se hacen de este fruto por los extranjeros para Curazao y otras partes y sin que paguen cosa alguna" se originaron precisamente numerosas solicitudes de exención del almojarifazgo sobre el cacao producidos en los Valles de la costa, amén de indemnizaciones a los cosecheros. En otros casos, los holandeses se introducían directamente en Tierra Firme, como fue el caso en el Valle de Cúpira, en las inmediaciones de la Provincia de Cumaná ${ }^{12}$.

Los holandeses no fueron los únicos en asentar su dominio comercial en el área caribeña y desarrollar prósperas colonias mercantiles institucionalizadas desde la misma Península (Cádiz), encaminadas incluso en contrarrestar "toda clase de disidencia dentro de su imperio marítimo" y de la "comunidad atlántica"(pax holandesa versus piratería $)^{13}$. Aprovechando los cambios experimentados por la economía cubana de la segunda mitad del siglo XVIII desde la toma de La Habana en 1762, este puerto se afirma como principal puerto exportador de la isla mientras el azúcar llega a ser el

\footnotetext{
12 Aizpurua, Ramón: Curazao y la costa de Caracas: introducción al estudio del contrabando en la provincia de Venezuela en tiempos de la Compañia Guipuzcoana, 1730-1780, Caracas, Academia Nacional de la Historia, 1993, pp. 257 y ss. AGI, Caracas, 438: el gobernador de Caracas a la Corona, Caracas, 14 de noviembre de 1763. Otra carta, del 27 de abril de 1765. Informe del fiscal, Consejo de Indias, Madrid, 13 de diciembre de 1763. Una Real Resolución de 1 de octubre de 1720 ya les advertía a los gobernadores (especialmente en el caso de las provincias de Caracas, Cumaná y Maracaibo) la necesidad de ponerles término a estas extracciones indebidas y repetidos "abusos". El Gobernador de Caracas a la Corona, con testimonio de autos, Caracas, 15 de junio de 1763.

13 Crespo Solana, Ana: Mercaderes atlánticos. Redes del comercio flamenco y holandés entre Europa y el Caribe, Córdoba, Universidad de Córdoba-Servicio de publicaciones, 2009, pp. 18, 157, 233 y ss.
} 
primer rubro de exportación, y los ingleses se convirtieron en los grandes proveedores del mercado urbano de la isla (tejidos, productos manufacturados). La Habana, núcleo estratégico del Caribe y del Golfo de México, plaza fuerte y base naval de la flota para la defensa de las rutas comerciales y punto de abastecimiento para barcos y buques españoles, terminó integrándose bajo la ocupación británica al sistema comercial y financiero del norte del Atlántico, con su centro en Londres. Como 25 comerciantes británicos -empresarios privados quienes actuaron como agentes o comisionistas de casas comerciales en Londres o Glasgow- y norteamericanos mantuvieron relaciones comerciales con La Habana en los años de la ocupación (1762-1763). Lo interesante del caso fue que, si bien los ocupantes abolieron ciertas instituciones españolas (alcabala, almojarifazgo, avería), los "negreros británicos" sí garantizaron la introducción continua de mano de obra esclava (la abolición del comercio de esclavos transatlántico no se dio sino hasta 1807, luego de la Revolución haitiana).

Hasta 1748, la South Sea Company opera desde Jamaica, después de la pérdida de su concesión, anulada por la Corona española. Sin embargo, parece ser que ni la Compañía de La Habana ni los asentistas particulares lograron zanjar la demanda. Se calcula que entre 1729 y 1761, se introdujeron legalmente unos 5.000 esclavos a Cuba. Durante los meses de la ocupación británica, fueron entre 3.000 y 4.000 (ni la mitad del número registrado en Jamaica pero más de los 200 esclavos introducidos anualmente en la isla hasta 1762). En este sentido, las reformas borbónicas y la recuperación de la isla de Cuba por la Corona española no tuvieron las consecuencias deseadas. Beneficiados anteriormente por la "prosperidad británica", los criollos no tardaron en lamentar la ineficiencia del gobierno colonial y exigieron reformas, especialmente la disminución de los impuestos y el reestablecimiento del tráfico comercial entre los puertos cubanos (Santiago de Cuba, Bayamo, Trinidad, y Puerto Príncipe) con puertos españoles (Barcelona, Málaga, La Coruña, Bilbao) o de la franja atlántica (Nueva Orleans, Cartagena, Veracruz). Dentro de los reclamos formulados está la firma de contratos con los esclavistas británicos de Jamaica, decisión llevada a efecto por uno de los nuevos representantes de España en la isla, el gobernador mariscal de campo Alejandro O'Reilly (firma de contratos con ingleses esclavistas, introducción de productos manufacturados), quien contribuyó en insertar la isla en el comercio transatlántico, flexibilizando así el sistema colonial ${ }^{14}$.

Con la anhelada sustitución del monopolio comercial de Cádiz por el comercio libre, La Habana comerció no sólo con otros puertos de España sino también con otros puertos caribeños como Santo Domingo, Trinidad, Puerto Rico y Margarita, aprovechando la reducción de los impuestos sobre introducción de esclavos $(41.000$ fueron introducidos por los esclavistas británicos durante los siguientes 25 años) y mercancías, en mayor provecho de la nueva oligarquía habanera, conformada por hacendados y comerciantes. De hecho, la sacarocracia cubana siguió tejiendo relaciones óptimas con los ingleses, en perjuicio de los comerciantes peninsulares. Otro tanto sucedió a favor de los norteamericanos, especialmente a partir de 1775, a raíz de la rebelión de las trece colonias contra Gran Bretaña, y en todo caso después del

14 Bottcher, Nikolaus: «Comerciantes británicos y el comercio interior de Cuba, 1762-1808», en BotTCHER, HAUSBERger e IBARRA (eds.): op. cit. (nota 11), pp. 207-13. 
Tratado de París (en 1763 Luisiana pasa a ser española y se incorpora a la capitanía general de La Habana) con el mayor disgusto de los agentes británicos instalados en Jamaica y proveedores de esclavos (pese a las relaciones mantenidas con Santo Domingo, Florida y Puerto Rico). Dependiendo de 1775 a 1783 de los comerciantes norteamericanos para la importación de alimentos básicos, La Habana se concentró en un monocultivo y la exportación del azúcar, que sobrepasaba la capacidad de la flota española. De ahí la llegada de comerciantes norteamericanos oriundos de Filadelfia, Baltimore pero también de Georgia, Carolina, Nueva Inglaterra o Nueva York, quienes ofrecían transporte a precios más bajos: en 1781, 126 buques mercantes arribaron a La Habana y en 1783 se inauguró la línea marítima entre La Habana y Filadelfia ${ }^{15}$.

Se señala sin embargo que con el fin de la guerra entre España e Inglaterra se redujo la presencia militar en Cuba. La importación de alimentos se hizo en adelante desde Nueva España o la misma metrópoli, y se revocaron las concesiones comerciales a los norteamericanos, bajo presión del Consulado de Cádiz. El esquema del comercio insular no dejó de ser sin embargo bastante simple, al reflejar además en sus distintos niveles y ámbitos los vaivenes de la presencia extranjera de acuerdo con los sobresaltos de la política metropolitana: "la economía de Cuba estaba determinada cada vez más por un monocultivo, por lo cual dependía de mercados externos para el abastecimiento de su población. Se importaban esclavos, carne y harina desde Jamaica y Estados Unidos. Los esclavos y los alimentos se compraron con el azúcar. El negocio estaba dominado por el comerciante extranjero, el político español y el dueño de plantaciones en Cuba" ${ }^{16}$.

Las figuras más destacadas entre los extranjeros fueron el comerciante Robert Morris (Filadelfia), Philip Allwood, delegado de los asentistas Baker y Dawson, de Liverpool. El mismo monopolio para la importación de harinas fue concedido por el ministro Godoy a Francisco de Arango y Parreño, el contrato negociado por el embajador español en EEUU y el cónsul norteamericano en Cádiz. En esa oportunidad fueron contratadas las casas comerciales de Josuah Donath \& Cía., Robert Gilmore \& Cía., y Philip Nicklin \& Cía., de Filadelfia y Baltimore. Fue el "triunfo del comerciante extranjero", especialmente como acreedor, en un contexto de dependencia creciente y de ausencia de otras fuentes crediticias en el Caribe cubano. La revolución de Santo Domingo en 1791 convirtió a la isla en el núcleo soñado de un imperio de plantaciones entre Norteamérica y las Antillas y en octubre de 1795 se firmó un tratado de navegación entre España y Estados Unidos. Por quedar España ocupada y en guerra en los años 1796-1808, la élite criolla cubana y su consulado (en virtud del reglamento de 1792) llegó a comerciar más con Estados Unidos que con la metrópoli, siendo los intereses de la isla los del productor de azúcar, y juntándose los intereses del hacendado habanero y del comerciante extranjero ${ }^{17}$.

\footnotetext{
15 Ibidem, pp. 207-213.

16 Ibidem. El subrayado es nuestro.

${ }^{17}$ Ibidem, pp. 215-229. Sobre este particular, véase también Sorhegui D’MARES, Arturo: «El puerto de La Habana: de principal enclave del comercio indiano a cabecera de una economía de plantación», en CARo, Jorge Enrique Elías y Vidal Ortega, Antonino: Ciudades portuarias en la gran cuenca del Caribe. Visión histórica, Barranquilla, Universidad del Magdalena-Universidad del Norte-Ediciones del Norte, 2010, p. 82.
} 
La presencia inglesa en la franja continental del Caribe siguió siendo sin embargo objeto de preocupación de las autoridades locales. En 1783, se señalan las "hostilidades cometidas por la tripulación de un bergantín inglés de la isla Barbada en los Pueblos de Irapa y Soro jurisdicción de Cumaná". Y la "satisfacción" que de ellas se le pidió a la "Corte de Londres". En 1802, el Gobernador de la Provincia de Caracas, don Manuel Guevara Vasconcelos, informa acerca de la "osadía" y de la "amenaza de invasión" de los mismos, en un contexto de conspiración abortada (Gual y España en La Guaira, 1797) y de continuas operaciones extranjeras en las costas venezolanas. Se sabe en efecto que los franceses de Guadalupe organizaron "expediciones" contra la isla de Curazao "de la nación batava", "suceso el más extraño y de modo alguno esperado" en las palabras del gobernador quien advierte lo "crítico y peligroso de estas circunstancias". Recalca sin embargo que logró "conservar la armonía correspondiente con los vasallos de las dos naciones aliadas entre sí, y ambas amigas de nuestro soberano, sin comprometer nuestro decoro". Luego de entregarse Curazao a los ingleses, resolvió además "cortar la fácil comunicación de estas provincias [Caracas] con aquella colonia considerada como nuestra enemiga". La "fanfarronada" inglesa lo llevó también a tomar medidas y a poner "sobre las armas las milicias de esta capital, Valles de Aragua y Valencia, por tiempo de dos meses, con el doble objeto de hacer ver a los enemigos que estaba prevenido para que desistiesen de cualquier intento".

Con el mismo fin de "intimidar" al enemigo, y habida cuenta de que la provincia de Caracas carecía en ese preciso momento de tropas, armas y municiones (no se pudieron adquirir ni en las colonias amigas) hizo construir 18 lanchas cañoneras que "guarnecen y defienden las costas de Guayana, Cumaná y Maracaibo", anteriormente "desamparadas y abiertas", logrando así desechar las pretensiones enemigas. La preocupación de Guevara Vasconcelos por contrarrestar las actividades de los "enemigos externos e internos" y "malos vasallos" presos de "esperanzas seductoras" y sus repetidos intentos por sublevar la provincia fue una constante durante sus años de gobierno. En el mismo orden de ideas, manifestó en repetidas oportunidades las "graves causas" que llevaron a "suspender la introducción y extracción de efectos y frutos en la América neutral" y motivaron la promulgación de la Real Orden del 20 de abril de $1799^{18}$. Desde principios de 1797, fecha en que la isla de Trinidad se entregó a los ingleses ("rendición y entrega") el gobernador inglés de ésta no dejó de reclamar ("exigir con violencia") además depósitos ( 7.774 pesos y 6 reales), ya gastados por la Real Hacienda en defensa precisamente de la misma isla y en buques de guerra. La ocupación casi simultánea de Santo Domingo no contribuyó poco a reforzar la presencia británica en el Caribe insular y en poner a la defensiva los gobernadores de las provincias hispanas en el continente $(1793-1798)^{19}$.

\footnotetext{
18 AGI, Caracas, 60: Manuel de Guevara Vasconcelos a José Antonio Caballero, Caracas, 28 de enero de 1801. Índice de la representación que remite el Gobernador Capitán General de Caracas al Excmo. Sr. Don Miguel Soler, secretario de Estado y del Despacho de Hacienda, 7 de diciembre de 1799. AGI, Caracas, 364: Índice alfabético de los expedientes del negociado de Caracas desde 1760 a $180 \ldots$ ".

19 AGI, Caracas, 457: Mariano Luis de Urquijo (por indisposición de Don Francisco de Saavedra) a Don Miguel Cayetano Soler, San Lorenzo, 5 de diciembre de 1798. Representación de los ex-ministros de la Real Hacienda de Trinidad, José Ramón de Mujica, Manuel Sorzano, Madrid, 27 de julio de 1799. Don Francisco Javier de Clipe, del
} 
El tema de los esclavos de temperamento revoltoso -en Venezuela las "cumbes" y "rochelas" nutren el imaginario de las élites como de la plebe conformada por afrodescendientes y mestizos- terminó siendo en estas condiciones el componente foráneo más duradero de las ansiedades manifestadas por las sociedades locales pese al continuo proceso de mestizaje que se dio en la provincia. Para finales del siglo XVIII, la población de color, los "libres de color/de castas" representan en el Caribe hispano un "enemigo interno" poco propenso a negociar según las pautas establecidas por las administraciones imperiales o sus agentes comerciales, y tampoco como esos "agentes viajeros como nexos de la cooperación transnacional" evocada anteriormente (Crespo Solana). Esta afirmación del "enemigo interior" se da además en un contexto ampliamente subrayado y comentado de comienzo de las "revoluciones políticas": recordemos tan sólo, a escala transatlántica - pero otro tanto podría decirse a nivel local- el resquebrajamiento del Imperio británico a raíz de la Revolución americana de 1776-83 y la publicación de una constitución ejemplar para no pocos Estados en ciernes en la región, las consecuencias de la Revolución francesa de 1789 que no sólo incidió en el equilibrio político europeo sino que también se trasladó a América a través de sus principios e ideas más notables. La Revolución haitiana, considerada con frecuencia como la mayor y más desgraciada y temible extensión de la revolución gala, fue de hecho el acta de nacimiento del segundo Estado libre (1804) de un espacio independiente cercado por sociedades esclavistas ${ }^{20}$.

\section{LA CIRCULACIÓN DE LAS IDEAS Y SUS VECTORES: EXTRANJEROS Y ESCLAVOS, UNA TEMIDA CONJUNCIÓN}

Si bien fueron múltiples las "rutas hacia la soberanía" incluso en el ámbito del Caribe hispano, no hay sin embargo que menospreciar el impacto continental de unas revoluciones estrechamente vinculadas con el tema de la esclavitud y de su abolición: de ahí no sólo la razón de ser y la presencia notable de ejércitos imperiales en el área caribeña y especialmente de tropas francesas, sino también de ingleses, con las consiguientes pérdidas (más de 50.000 soldados y marineros a raíz de la "revolución haitiana") ${ }^{21}$. Más que consideraciones de tipo religioso ("herejía" en el caso de los ingleses y holandeses) y a diferencia del contexto de principios del siglo (la guerra

\footnotetext{
Consejo de SM su secretario y escribano de Cámara en el Real y Supremo de las Indias, certificación dada en Madrid, 14 de febrero de 1801. Real Orden de 19 de abril de 1800 "aprobando las satisfacciones y descargos dados a los juicios de cuentas de las Reales Cajas de Trinidad, respectivos a los años de 1791 a 1795". Para 1803, se encuentra una autorización a favor de D. Manuel Sorzano de Tejada para pasar de Cádiz (había regresado a España luego de la pérdida de Trinidad donde residía) a Trinidad a recoger a sus hijos ("diez hijos de tierna edad huérfanos de madre") y disponer la enajenación de los bienes (disponer de sus bienes) que tenía en esa isla, acompañado por 4 criados ( 2 de color) para regresar luego a España.

${ }^{20}$ Geggus, David (ed.): The Impact of the Haitian Revolution in the Atlantic World, Columbia, University of South Carolina, 2001. CRESPO SOlAnA, Ana: «¿Redes de dependencia inter-imperial? Aproximaciones teóricas a la funcionalidad de los agentes de comercio en la expansión de las sociedades mercantiles», en PÉrez Tostado, Igor y García hernán, Enrique (eds.): Irlanda y el Atlantico Ibérico. Movilidad, participación e intercambio cultural, Valencia, Albatros Ediciones, 2010, p. 39.

${ }^{21}$ Klooster, Wim: Revolutions in the Atlantic World. A Comparative History, New York University Press, 2009, p. 117.
} 
de Sucesión y sus avatares de ultramar), son las veleidades revolucionarias las que llaman la atención en las postrimerías del período colonial. Además, obligan a pensar las relaciones no sólo en tiempos de guerra sino las modalidades de propaganda y circulación de la información en semejante contexto. Gestores de la revuelta in situ como lo fueron los cabecillas de la población de color y personajes de dudosas intenciones e inesperado actuar como los corsarios o viajeros no oriundos de los territorios bajo soberanía de la Monarquía hispánica tienden en ese aspecto a romper los esquemas organizativos que prevalecieron hasta aquel entonces. Otro tanto podría decirse de la violencia inédita que nutre y con la que se encuentran, en los hechos y en las prácticas discursivas, las diversas formas de resistencia o subversión que asoman en el ámbito caribeño de fines del siglo XVIII ${ }^{22}$.

Revolución, corsarios y esclavos rebeldes/fugados/marrones son unos de los elementos más destacados de la circulación de hombres e ideas foráneas en el Caribe de fines del siglo XVIII y hasta de la segunda mitad del siglo, a través de conflictos pero también de renovadas alianzas diplomáticas. Anne Pérotin ha subrayado las consecuencias de estos contactos de larga duración establecidos a través de las islas francesas y particularmente de Guadalupe hacia el arco caribeño, de Cuba a Venezuela, poniendo de relieve la personalidad singular del enviado de la Revolución a la isla, Víctor Hugues. Este personaje actuó primero como comisario de la Convención y luego, como agente del Directorio a partir de 1796 (aunque sin instrucciones formales aparte del avituallamiento de Saint-Domingue). Se mostró particularmente activo a la hora de luchar contra los ingleses apoyándose en la presencia realista española en el área, alianza considerada como duradera en lo social e ideológico (y de cierta forma en lo militar si consideramos el apoyo prestado a España luego del tratado de Bâle en 1795 y cuando los ingleses atacan Trinidad en 1797). Venció de esta forma tanto las reticencias originadas en las fronteras sociales de los unos y de los otros (plebe versus aristocracia) como en discursos antagónicos aunque circunstancial y prudentemente "callados" en el caso de los representantes de la Revolución (los lemas libertad e igualdad cundieron sin embargo entre los soldados, marineros, plantadores, esclavos, filibusteros, corsarios y aventureros). Conforme se van multiplicando asonadas, rebeliones y movimientos revolucionarios, un creciente número de republicanos franceses de Martinica, Guadalupe, Santa Lucía y Trinidad busca refugiarse en efecto en el continente (en la isla Margarita, en Barcelona, Cumaná, y hasta en Caracas) de tal forma que los patriotas de las pequeñas Antillas francesas se juntan con los precursores de las revoluciones hispanoamericanas: tal fue el caso con Miranda en 1810-12, y luego a favor de Bolívar hacia $1816^{23}$.

La interrupción de las comunicaciones con la metrópoli y la apertura del comercio a los llamados neutrales entre 1797 y 1801 (i.e. norteamericanos, daneses) mayor-

\footnotetext{
22 GonZAlEz CRUZ, David: «La construcción de imágenes sobre los extranjeros en España y América durante la Guerra de Sucesión: ingleses, holandeses, portugueses y franceses», en Gonzalez Cruz, David (ed.): Extranjeros y enemigos en Iberoamérica: la visión del otro del Imperio español a la Guerra de la Independencia, Madrid, Sílex, 2010, p. 99. Véase del mismo autor, Propaganda e información en tiempos de guerra. España y América (17001714), Madrid, Sílex, 2009.

${ }^{23}$ Perotin, Anne: «Révolutionnaires français et royalistes espagnols dans les Antilles», Caravelle, 54 (1990), pp. 223-246.
} 
mente desde Cuba y Venezuela se interpreta con frecuencia como una independencia en la práctica. Durante ese lapso de tiempo, las relaciones con los republicanos franceses se hacen más frecuentes. Hasta a los corsarios se les encarga - de forma puntual aunque no excepcional- llevar el correo y mantener las relaciones entre las colonias españolas: así en el caso de Trinidad, hay que señalar que el bloqueo inglés sólo se rompió gracias a los barcos franceses. Pese a la necesidad de esas relaciones marítimas alternativas, a la eficiencia casi militar de los corsarios galos, las autoridades españolas no dejan de temer sus consecuencias, o sea la difusión de los escritos sediciosos (Declaración de los derechos del hombre, la canción Carmañola americana), junto a la arrogancia que se les achacaba tradicionalmente a las tripulaciones francesas. Se menciona sin embargo el prestigio que tenían ante los "hijos de familia" -élites locales prontas a embarcarse en los barcos franceses como fue el caso en Puerto Rico- y hasta de los esclavos deslumbrados por aquellos "ciudadanos" de la libertad.

Hay que recordar sin embargo que la presencia corsaria se acentuó precisamente en la última década del siglo XVIII y especialmente a partir de 1796. De cierta forma se benefició del alejamiento forzado de Holanda, cuyas posesiones como Curazao quedaron en efecto bajo "protección" de los republicanos galos. De ahí también el "peligro" de subversión ideológica que coincidió con rebeliones en el Caribe insular (Jamaica en 1795, entre junio y abril de 1796 en las mismas Antillas francesas) en un momento en que la colonia francesa más próspera se encamina decididamente hacia la independencia ${ }^{24}$. La estrategia de Víctor Hugues, respaldada por los "blancos de orilla" de las colonias isleñas (petits blancs) y sustentada por su red de espías, consistió por una parte en detener la progresión inglesa y conservar las posesiones francesas en esa parte del Caribe insular. En esta perspectiva, la alianza con los españoles, el envío de ayudas y municiones, el uso de los puertos españoles como bases para los corsarios, participan de un realismo estratégico destinado a rescatar las islas ocupadas por los ingleses (Santa Lucía) o a desestabilizar al enemigo (en Granada y luego Curazao). El "miedo a la revolución" de parte de las autoridades de Tierra Firme (particularmente en Caracas) ante la perspectiva de ver a los esclavos y a la otra gente de color convertirse en ciudadanos junto a los petits blancs patriotas (petits colons, en oposición con los grandes plantadores), o, al contrario, que la abolición de la esclavitud lleve a la ruina de las colonias ("mal ejemplo" de Saint-Domingue) dificultó sin embargo sus propósitos.

En esta postura pragmática -la necesidad de la abolición- se va a asentar sin embargo la diplomacia de V. Hugues, especialmente ante las autoridades de Santo Domingo o de Caracas, así como en la incorporación de una actividad corsaria con respaldo en puertos españoles. A los corsarios "formados" en el escenario de las guerras caribeñas y a los veteranos llegados de las guerras continentales se les unieron además algunos aventureros "vagabundos de la República", dicho de otra forma una "comunidad heterogénea de hombres de variadas procedencias, defensores de las ideas de libertad e independencia y dispuestos a trabajar juntos a favor de la causa republicana". Tal fue el caso de Louis-Michel Aury, quien se formó en el Caribe y atacó

${ }^{24}$ Ibidem, pp. 227-229. Geggus, David P.: Slavery, war, and revolution: the British occupation of Saint Domingue 1793-1789, Oxford, Clarendon Press, 1982, pp. 203-205. 
los barcos ingleses bajo los órdenes de V. Hugues, para luego refugiarse en Luisiana y armar por su cuenta una flotilla, ascender a comandante en jefe de la República y luego refugiarse en Venezuela, Providencia y San Andrés.

Corsarios no portadores de la correspondiente carta de reconocimiento (patente de corso o lettre de marque), renegados, todos fueron "patriotas itinerantes" reacios a la autoridad estatal más que portadores de una ideología definida, incluso cuando un decreto del 16 de agosto de 1811 amenazó con embargar los bienes de los franceses empleados de una potencia extranjera. Se considera incluso que para un período posterior (que sobrepasa el ámbito cronológico de este estudio), el de las primeras repúblicas (1810-1815) y luego de las guerras de independencia y de consolidación de los nuevos estados (1816-1827), se afirmó la presencia corsaria francesa en las huestes libertadoras ("corsarios insurgentes"): a uno de los representantes más notables del corso bolivariano, Nicolás Joly, le rindieron los honores de prócer cuando murió en Venezuela. El aspecto más notable de los casos encontrados fue el igualitarismo manifestado a favor de la población de color criolla, que coexistió a veces con una defensa de la esclavitud y hasta con el comercio de esclavos (caso de Aury, rodeado de colaboradores cosmopolitas y de mucha gente de color) ${ }^{25}$.

La fuga de negros esclavos constituye otro capítulo fundamental de las reclamaciones formuladas por los representantes de los imperios ante la Corona española, junto a otro capítulo "sensible", el de los desertores en tiempos de guerra. Entre las consultas recibidas por el Consejo de Indias figuran solicitudes de los ingleses y también del rey de Dinamarca, quienes piden que los negros fugitivos que se pasan a las colonias españolas les sean restituidos. Igual pretensión formularon estas naciones acerca de los desertores a partir del 9 de mayo de 1768. En 1786, el embajador de Francia pide que se le restituyan 24 negros que se habían pasado del Esequibo al Orinoco, solicitud denegada por declararse las autoridades imposibilitadas (gobernadores de la Guayana española y el capitán general de Caracas incluidos). El embajador de la "Corte de Francia" en Madrid, el conde de Montmorin, denunció el pretexto alegado por los negros fugitivos, el de haber abrazado la religión católica. Uno de los aludidos, un "moreno libre natural de Cabo Verde", Alejo de Can, había sido "llevado a la Granada de joven y vendido luego a un amo de Santa Lucía con otro compañero, Juan Bautista". Ambos eran peluqueros de oficio, pero Alejo de Can dijo hallarse con una tienda de ropa en Cumaná, y pidió que se le dejara en libertad "por un precio justo de acuerdo con lo prometido", solicitud aprobada por el gobernador de Cumaná, quien acreditó su "buena conducta" 26 .

\footnotetext{
${ }^{25}$ Perotin: op. cit. (nota 23), pp. 239-246. Vidales, Carlos: «Corsarios y piratas de la revolución francesa en aguas de la emancipación hispanoamericana», Caravelle, 54 (1990), pp. 247-262. MongEy, Vanessa: «Les vagabonds de la république: les révolutionnaires européens aux Amériques, 1780-1820», en Morelli, Federica, THIBAUD, Clément y VERdo, Geneviève (eds.): Les Empires atlantiques des Lumières au libéralisme (1763-1865), Rennes, PUR, 2009, pp. 67-82.

${ }^{26}$ AGI, Indiferente, 801: solicitud del 9 de mayo de 1768 (en Consejo). AGI, Caracas, 364: "Índice alfabético de los expedientes del negociado de Caracas desde 1760 a 180...”. AGI, Caracas, 426: Testimonio de Da Felipa Caro, viuda de Don José Antonio de Zarraga, como tutora de hijos menores, al Presidente Gobernador, con motivo del tratado de paz con la República francesa de Santo Domingo. Alude a los "graves quebrantos" que sufrió al salir precipitadamente de la isla de Santo Domingo, perdiendo sus bienes y 11 esclavos (20 de abril de 1796). Sentencia de la Audiencia, Caracas, 10 de diciembre de 1796 (sublevación del zambo libre José Leonardo Chirinos, condena a
} 
Junto a esta modalidad de la circulación de la gente de color en el Caribe, asoma sin embargo aunque de forma ocasional y hasta cíclica el "miedo a Santo Domingo", dicho de otra manera el miedo a que se repitan in situ los siniestros acontecimientos de Haití, y más cuando las circunstancias locales parecen hacerse eco de los mismos como fue el caso durante la sublevación de los "negros jacobinos" de la serranía de Coro (1795) más precisamente del "zambo libre Chirinos", y en los años sucesivos. Hay que subrayar sin embargo que el "miedo a Haití" no resultó tan difundido en las prácticas de las autoridades y de las élites locales como lo fue... en la historiografía sobre el particular donde se ha sobrevalorado -por lo menos hasta 1793, cuando se abrieron las hostilidades en la isla La Hispaniola con motivo de la guerra de la Primera Coalición contra la República Francesa- el impacto de la "Revolución haitiana" y de sus "masacres" y "sangrientos horrores" junto al discurso de los "precursores" de la Independencia ${ }^{27}$.

En muchos casos, las noticias sobre el acontecimiento haitiano se añaden a un ambiente nada reciente de desconfianza e incluso de rivalidad comercial o política (guerras europeas) para con los vecinos extranjeros y especialmente las colonias extranjeras. En la correspondencia de los gobernadores y capitanes generales caraqueños, aparece con mayor nitidez el tema de las revueltas acaecidas en las islas vecinas (caso de Martinica a principios de los años noventa, punto de partida de la emigración hacia Tierra Firme, incluso de oficiales contra-revolucionarios) y de la proximidad de las "naciones enemigas". Ahora bien, coincidimos con A. Ferrer en subrayar que las omnipresentes referencias a Haití, por más que llevaron a las élites locales a renunciar a la posibilidad de obtener su independencia (caso de las élites criollas cubanas, confrontadas a la llegada de los refugiados/plantadores de la colonia francesa por millares, muchos con esclavos) o a intentar controlar la muy informada (respecto a los sucesos de Haití) revoltosa y díscola plebe de los pardos y esclavos libres (caso de Venezuela) no fueron sino rumores persistentes aunque muy sugestivas,

meras referencias, alusiones vagas, evocaciones sin contenido explícito. Pero por imprecisas que fueran esas menciones, parecían tener el poder de transmitir imágenes concretas, de aclarar o ilustrar un argumento sin necesidad de elaboración ulterior ${ }^{28}$.

\footnotetext{
los cabecillas). Don Silvestre Collar y Castro al Consejo de Indias, Madrid, 3 de febrero de 1798. AGI, Caracas 286 José de Gálvez, El Pardo, 27 de febrero de 1783, asunto visto en el Consejo, 6 de marzo de 1783. El Gobernador de Cumaná, Cumaná, 26 de agosto de 1785 .

27 Aizpurua, Ramón: «La insurrección de los negros de la Serranía de Coro de 1795: una revisión necesaria», Boletín de la Academia Nacional de la Historia, Caracas, vol. LXXI, 283 (1988), pp. 707-710. GómEZ, Alejandro E.: «La Revolución Haitiana y la Tierra Firme hispana», Nuevo Mundo, Mundos Nuevos, 6 (2006): http://nuevomundo. revues.org/211

${ }^{28}$ FerRer, Ada: «Temor, poder y esclavitud en Cuba en la época de la Revolución haitiana», en PiQuERAs, José A. (ed.): Las Antillas en la era de las Luces y la revolución, Madrid, Siglo XIX, 2005, pp. 68-69. Sobre refugiados franceses en otras islas del Caribe y el proceso de asentamiento de los extranjeros mediante la Real Cédula de gracias al sacar, remitimos al estudio de LuQue, María Dolores, publicado en la misma obra: «Revolución e inmigración francesa en Puerto Rico, 1789-1815», pp. 123-138.
} 
Las formas de la rebelión y de incorporación en las huestes independentistas fueron en realidad mucho más complejas de lo que sugieren las referencias a Haití, tanto de parte de los amos como de los esclavos interesados respectivamente en preservar la disciplina en sus tierras y reclamar buenos tratos, uso de un pedazo de tierra ("conuco") y hasta libertad para sí mismos o sus familias. Además, no siempre remitían a una influencia exterior fuera de sucesos puntuales y limitados en el tiempo, entre ellos las rebeliones y conspiraciones locales como se comprueba en el caso venezolano. En cambio, lo que sí influyó en la percepción que del evento se tuvo o mejor dicho del "síndrome" que cuajó en las postrimerías del siglo XVIII, fue la migración masiva e incluso el "éxodo" de refugiados a raíz de las primeras insurrecciones de los mulatos haitianos en julio de 1790 y a lo largo del año 1791: de los 40.000 blancos registrados en Saint-Domingue antes de 1789 (28.000 libres de color y más de 500.000 esclavos), una mayoría se fue tras la insurrección de 1791 a buscar fortuna en los distintos territorios insulares o continentales del Caribe, dicho de otra manera en las otras sociedades esclavistas de la cuenca caribeña. Algunos regresaron bajo el régimen de Toussaint Louverture aprovechando la fase "tolerante" del mismo (1799) y a consecuencia del éxito inicial del ejército expedicionario enviado por Napoleón. Se considera que para mediados de 1804, casi no quedaban blancos en el territorio: 9.000 se refugiaron en Cuba (hasta la ocupación napoleónica de la Península), de forma más esporádica en Venezuela, y en Estados Unidos y particularmente en Nueva Orleans a partir del año 1793 y muy a menudo con escala previa en Cuba. Pese a las restricciones impuestas por la legislación española, el destino privilegiado fue la otra parte de la isla, o sea Santo Domingo y especialmente su zona fronteriza ${ }^{29}$.

La presencia del inglés, convertido en enemigo común, llegó a justificar esa suerte de "neutralidad ideológica" que impera en aquel entonces entre los representantes coloniales de España y Francia y de que se benefició la numerosa flota de corsarios formada por el comisario de la Convención Nacional en Guadalupe, Víctor Hugues. La desconfianza manifestada posteriormente por las autoridades españolas de Tierra Firme, a pesar de las muchas armas y municiones con que les proveían los franceses, tuvo que ver con la experiencia de 1795, en la medida en que eran conocidos los contactos establecidos por los corsarios galos con los cabecillas de la sublevación de Coro. También habría que mencionar por otra parte el papel que desempeñaron algunos agentes franceses, quienes se dedicaban a promover "regímenes de emancipación" parecidos a los sistemas implantados en las islas francesas, como fue el caso del agente francés en Santo Domingo, Philippe Roume. Otras razones de esta desconfianza aparecen a todas luces con la llegada de refugiados blancos provenientes de Santo Domingo (1795) huyendo el régimen de Toussaint Louverture (1801). También habría que mencionar la conspiración de Gual y España, movimiento insurreccional de inspiración jacobina, encabezado por "blancos criollos" y pardos de las ciudades de Caracas y La Guaira (junio 1797), de que se presume que lo apoyó desde Guadalupe Víctor Hugues; y luego, el intento por sublevar a los pardos de Maracaibo de

29 Gómez Pernía, Alejandro: Le syndrome de Saint-Domingue. Perceptions et représentations de la Révolution Haïtienne dans le Monde atlantique 1790-1886, tesis de doctorado EHESS, París, 2010, pp . 85 y ss. Disponible en http://tel.archives-ouvertes.fr/tel-00555007/en/ 
parte de dos corsarios procedentes de Puerto Príncipe (mayo de 1799), episodio en que presuntamente participaron los mulatos franco-dominicanos del partido de André Rigaud.

El temor al "contagio revolucionario", a la "propagación de las ideas perjudiciales" de los franceses establecidos en Santo Domingo o en Martinica, de los corsarios y otros propagandistas, se origina más bien en los años que siguieron la Revolución francesa (1789). No sólo la Audiencia de Caracas por medio de su regente, sino también los gobernadores capitanes generales Pedro Carbonell y Manuel de Guevara Vasconcelos, denuncian la pretensión manifestada por los agentes procedentes de Guadalupe de introducirse en Venezuela por Curazao o Trinidad, y el riesgo que conlleva la "insubordinación" presente en "máximas tan nocivas", "gacetas" y otros "papeles sediciosos (...) perjudiciales a la pureza de la religión y a la quietud pública". No dejan de mencionar el Manifiesto de la Asamblea de París (Convención) dirigido a todas las naciones, y obviamente los Derechos del Hombre, traducido e impreso por Nariño en Bogotá y que circulaba en el virreinato de Nueva Granada desde 1794. Otro folleto posterior, del año 1799 e impreso en la isla de Guadalupe, en que se citaban máximas republicanas (autor presunto Juan Bautista Picornell), despertó las inquietudes de las autoridades de Tierra Firme y especialmente de la ciudad de Caracas. Las medidas de extremada vigilancia tuvieron como consecuencia la persecución y la expulsión de los extranjeros establecidos en la Capitanía General, especialmente de los franceses. Estas medidas preventivas incluyeron el allanamiento de casas, así en el caso del comerciante francés Santiago Albi, para investigar si tenía papeles relacionados con la Convención de París, y el embargo de bienes pertenecientes a comerciantes franceses instalados en la Capitanía General ${ }^{30}$.

En el Caribe hispano, la política del "cordón sanitario" respaldada por las élites criollas locales se dirige fundamentalmente a impedir la llegada no sólo de franceses sino de "negros franceses" y otros libres de color procedentes de las islas francesas. Desde el 21 mayo de 1790, una Real Orden prohíbe la entrada de negros comprados o fugados de las colonias francesas así como de cualquier otra casta que pudiese influenciar a los vasallos. De ahí las numerosas expulsiones que se produjeron, tanto en Venezuela como en Cuba, especialmente en el año 1792 (véase la orden dada al co-

${ }^{30}$ IzARD, Miguel: El miedo a la Revolución. La lucha por la libertad en Venezuela (1777-1830), Madrid, Tecnos, 1979; PÉrotin Dumont, Anne: «Sous ce soleil brûlant: recherches sur les Jacobins des Antilles», Bulletin d'Histoire de la Révolution Française, años 1984-85, París, Comisión de Historia de la Révolución Francesa, 1987, pp. 2344. AGI, Estado, 65 (20): el capitán general Pedro Carbonell al duque de Alcudia, Caracas 31 de agosto de 1794; Archivo General de la Nación, Venezuela (en adelante AGNV), Reales Órdenes, X: el capitán general a Antonio Porlier, 24 de septiembre de 1789; Reales Órdenes, XII: R.O. de 7 de junio de 1793; Carbonell al Regente, 22 de agosto de 1793; Reales Órdenes, XIII: R.O. al Capitán General, Aranjuez, 29 de enero de 1795. CALLAGHAN, William J: «La propaganda, la sedición y la Revolución Francesa en la Capitanía General de Venezuela, 1789-1796», Boletín Histórico (Fundación Boulton), 14 (mayo de 1974), pp. 177-205; AGI, Estado, 58 (18, 30): la Audiencia de Caracas al Secretario de Estado, 10 de mayo de 1799; el presidente de la Audiencia a Manuel de Guevara Vasconcelos, Caracas, 22 de junio de 1799. AGNV, Gobernación y Capitanía General, LIll (129-140) y Aragua, XXXIV (18): el capitán general al teniente coronel F. de Albuquerque, Caracas, 29 de noviembre de 1794; AGI, Estado, 67: P. Carbonell al Príncipe de la Paz, 18 de abril de 1797; la Real Cédula del 22 de mayo de 1795 contempla la expulsión de los extranjeros de los reinos de América. Abordamos este tema del "miedo a la Revolución” en Langue, Frédérique: Aristócratas, honor y subversión en la Venezuela del siglo XVIII, Caracas, Academia Nacional de la Historia, 2000, pp. 141-145. 
mandante del pueblo de Barbacoa en este sentido): por esta misma razón, un genovés, autorizado sin embargo a establecerse en la isla, tuvo que renunciar a introducir a sus 30 esclavos. La situación de las autoridades se complicó sobremanera con la llegada de esclavos incorporados a grupos de prisioneros como fue el caso en 1793 con la llegada de 200 negros, algunos de ellos listos a proclamar su próxima liberación. Siempre en Cuba, y habida cuenta de que se seguía introduciendo a negros franceses en la isla pese a las restricciones, el gobernador amenazó con multar a los transgresores. Un certificado de origen se les exigió asimismo a los dueños de esclavos y "para evitar doctrinas perniciosas", se decidió expulsar de la isla a los esclavos franceses que habían llegado después de 1790 (o sea un año antes de la insurrección haitiana de la Plaine du Nord) así como a los esclavos ingleses introducidos después de 1794. Otra disposición de 1798 contempló el arresto de los libres de color franceses en caso de que se atrevieran a desembarcar y la deportación inmediata de los mismos ${ }^{31}$.

De ahí las situaciones confusas que se presentaron cuando los emigrados llegaban acompañados por sus esclavos. Así sucedió en agosto de 1803 cuando llegaron a Cuba 500 individuos de color, libres y esclavos, junto con los numerosos franceses blancos huyendo Saint-Domingue. Éstos tuvieron que sacar a sus esclavos de la isla, en muchos casos vendiéndolos, mientras a los hombres libres de color mayores de 13 años se les destinaba a Tierra Firme. En Caracas, La Guaira y Cumaná, el mayor peligro radicó en la presencia de mulatos franco-antillanos que ostentaban el grado de oficiales como resultado de las "prácticas igualitarias introducidas en las colonias francesas desde 1792": resultó imposible desterrar a esos "republicanos franceses de color" con motivo del tratado de alianza militar firmado en 1796 con Francia. A esta emigración forzada se le unía la de los "negros republicanos" desde Curazao. A partir de 1801, situaciones similares se dieron entonces en Cuba con la llegada de partidarios de la facción de André Rigaud o del general Blanchet, rechazados por las autoridades locales, logrando algunos que otros mulatos sortear la vigilancia del gobernador y quedarse a escondidas en la isla. Hasta se dieron casos de esclavos franceses que al no poder ser vendidos de nuevo como "bozales" o de forma clandestina (varios militares franceses lo intentaron), fueron soltados, así en la península de la Guajira, donde los indios capturaron a esa inesperada mano de obra ${ }^{32}$.

Nos conformaremos por lo tanto con mencionar tan sólo unos ejemplos adicionales, y muy concretos de esa sensibilidad muy difundida entre las élites criollas blancas o al contrario entre la población de color en contra o a favor respectivamente de los lemas de libertad e igualdad, junto al tema de las revoluciones "de color", protagonizadas por negros libres y esclavos. Más que de una emoción, mucho más puntual en su expresión, se trata en efecto de una reacción difundida en todo el ámbito caribeño, que tienden a reforzar migraciones internas ocasionales protagonizadas en especial por "refugiados" españoles o por negros rebeldes que huyeron a Curazao, y las medidas tomadas al respecto para preservar las costas de tan peligrosa situación. Para 1797, el Presidente de la Audiencia de Caracas puntualizaba así que "la jurisdicción de Coro por su situación y producciones se halla expuesta al insulto de los

31 Gómez Pernía: op. cit. (nota 29), pp. 261-264.

32 Ibidem, pp. 263, 276. 
enemigos de la Corona" y subraya la necesidad de contrarrestar la decadencia de su comercio mediante la concesión de licencias para las colonias amigas e intentando restituir los bienes perdidos por españoles durante la revolución haitiana.

Después de esa fecha se multiplican las causas de infidencia por delito de opinión, y se prohíbe el "trato" con los habitantes de Santo Domingo (1801) con motivo de la sublevación del negro Toussaint Louverture, por considerar el Gobernador Capitán General que ésta era la única manera de conservar la provincia "en la paz y en la pureza de ideas". Asimismo se persiguen los impresos o manuscritos sediciosos, disposición que seguiría vigente hasta el año $1816^{33}$. El hecho es que uno de los implicados en la conspiración de Gual y España, Manuel Montesinos y Rico, vecino de Caracas, hacendado y comerciante, guardaba en su casa instrucciones para el establecimiento de la "Junta General" así como la famosa Canción Americana, en que se le insta al pueblo para que se rebele contra sus "opresores" 34 .

El año de 1802, año en que mejoraron sustancialmente las relaciones con Francia con la llegada al Caribe de la expedición enviada por el primer cónsul Napoleón Bonaparte con el fin de reestablecer el antiguo régimen colonial en las islas francesas, constituye un hito en las relaciones de las autoridades españolas con las colonias extranjeras. Sin embargo, no deja de incidir en el desarrollo del "síndrome haitiano" y de la correspondiente "ansiedad coyuntural" generada por la numerosa población de color, del esclavo negro al mulato, pardo, zambo u otro moreno. El Capitán General de Venezuela manifestó su satisfacción, pero, al igual que sus homólogos de Cuba, Nueva España y Nueva Granada y con el apoyo de las élites locales, también les prestó ayuda a los emisarios franceses para contrarrestar los designios del "escandaloso tirano de la Europa" (fundamentalmente dinero para que adquiriesen mulas, carne seca y hierbas medicinales). Para finales de 1803, luego de la exitosa intervención de las fuerzas expedicionarias galas en Martinica y Guadalupe, se está vislumbrando ya el repliegue en Saint-Domingue y en enero 1804 se declara la independencia de Haití:

hasta al menos 1797, [las autoridades españolas] habían seguido usando el referente de "mal francés" para referirse a todas las amenazas que implicaban tanto los "funestos" principios de la Ilustración como los "peligrosos" preceptos de igualdad y libertad de

33 AGI, Estado, 58 (8, 29, 31,33), 59 (14): correspondencia del capitán general con el secretario de Estado, 1796-1799, Estado 60 (14): el capitán general al secretario de Estado, 13 de julio de 1801. AGNV, Gob. y Cap. Gral., CXXXIII (191): orden al Gobernador de Guayana de recoger el libro titulado La Muerte de Robert Pierre. Caracas, 9 de septiembre de 1803; Causas de Infidencia, IV: expediente contra F.X. Briceño et la Junta Revolucionaria de Trujillo, 1812 (como lectores de los Derechos del Hombre); Aragua, LXXIII, LXXIII (31), LXXV (8). BRICEÑo Perozo, Mario: «Las causas de infidencia», en LóPez Bohórquez, Ali E. (presentación y selección): La Real Audiencia de Caracas en la historiografía venezolana (Materiales para su estudio), Caracas, Academia Nacional de la Historia, 1986, pp. 223-316.

34 AGI, Estado, 58 (18) y 59 (1, 6): la Audiencia de Caracas al Príncipe de la Paz, 23 de agosto de 1797 y 10 de junio de 1799. Gómez: op. cit. (nota 27). AGI, Caracas, 426: testimonios del Gobernador y del Presidente de la Audiencia de Caracas del 6 de marzo y de 29 de mayo de 1797 sobre providencias en la sublevación Coro. Menciona tanto la escasez de tropas, como la dificultad de asegurar la defensa de "aquellos partidos de situación peligrosa y cercanía a las colonias extranjeras". Se recuerda sin embargo que se sigue otorgando licencias para el comercio con las colonias amigas, se concede graciosamente sin derecho alguno y libertad de alcabala. El Presidente de la Audiencia de Caracas a la Corona: "La jurisdicción de Coro por su situación y producciones se halla expuesta al insulto de los enemigos de la corona" (Pedro Carbonell, Caracas, 29 de mayo de 1797). 
la Revolución Francesa. A partir de aquel momento, ese epíteto comenzó a ser sustituido por una suerte de "mal haitiano", el cual reflejaba la angustia ancestral a sucumbir a manos de un "negro alzado" con el temor potencial a que se implantase en la Tierra Firme hispana otra "república de negros" $"$.

Tal fue el caso en 1806, cuando llegó a las costas de Coro procedente de la joven república haitiana la expedición encabezada por Francisco de Miranda con el objetivo de independizar a Venezuela. Hay que señalar que el mismo Miranda llegará a manifestar su decepción ante los desórdenes de Haití y las modalidades revolucionarias de su independencia en 1804. Asimismo el contra-ejemplo haitiano cobra sentido en 1808, a raíz de la invasión de la Península Ibérica por las tropas napoleónicas, y hasta se alegó que la "conjuración de los mantuanos" podía haber derivado en otro Haití. La tercera ocurrencia nos lleva al año 1812 y más aún 1813 y a la guerra de Independencia de Venezuela en cuanto "guerra civil" (en las palabras de G. Carrera Damas), cuando abundan referencias al caso haitiano y a la violencia ejercida por los ejércitos de "todos los colores" y oficiales de ambos bandos, tanto patriotas como realistas. El rumbo político de la "Revolución haitiana", si bien apuntó a la igualdad de los mulatos, de acuerdo con el proyecto constitucional mirandino de 1806, no dejó de influir en ese aspecto en el debate acerca de la abolición de la esclavitud, tal como se evidenció en la Sociedad Patriótica caraqueña a partir de 1810, "sociedad de pensamiento" donde se juntaron no pocos exiliados de regreso de Puerto Rico, Cuba y Curazao. Ahora bien, y a diferencia del ejército realista, los patriotas venezolanos se resistieron hasta al menos 1814, cuando se percataron de que resultaba ineludible la participación de las huestes "de color" y cuando se beneficiaron también de la decisiva ayuda prestada por el gobierno de A. Pétion al gobierno republicano ${ }^{36}$.

\section{3. "HÉROES ERRANTES" Y OTROS MÁS (ALGUNAS FIGURAS) 37.}

No insistiremos mayormente en la cuestión de los militares extranjeros o de los mercenarios en el Caribe continental, aspecto fundamental de la circulación de los extranjeros en el Caribe hispano pero ya ampliamente tratado por varios autores, incluso en el caso del ejército del Libertador y para un período más tardío: como 7.000 ingleses,

\footnotetext{
35 Langue: op. cit. (nota 30), pp. 144-145; GómeZ: op. cit. (nota 27). Del mismo autor: «El Síndrome de SaintDomingue. Percepciones y sensibilidades de la Revolución Haitiana en el Gran Caribe (1791-1814)», Caravelle, 86 (2006), pp.125-156.

${ }^{36}$ GómeZ: op. cit. (nota 27); LANGUe, Frédérique: «El pensamiento venezolano de la emancipación y la conjuración de los mantuanos», III Congreso Latinoamericano de la Universidad de Varsovia, 16-18 de junio de 1995, Memorias, Varsovia, 1996, vol. 2, p. 97-105; LANGUE: op. cit. (nota 30), pp. 145-146; CARrera Damas, Germán: La Disputa de la Independencia y otras peripecias del método crítico en Historia de ayer y hoy, Caracas, Ediciones EG, 1995, p.12; GegGus, David: «Slavery, War and Revolution in the Greater Caribbean», en Gaspar, D.B. y GegGus, D.P.: $A$ Turbulent time (The French Revolution and the Greater Caribbean), Bloomington, Indiana University Press, 1997, p. 16.

${ }^{37}$ A semejanza de uno de estos viajeros atrevidos de la época de Bolívar, el cartógrafo italiano Agustín Codazzi, o también de esos corsarios y piratas que lucharon por la libertad de América. Expresión que retomamos del libro de AnteI, Giorgio: Los héroes errantes: la historia de Agustín Codazzi, 1793-1822, Bogotá, Planeta Colombiana Editores, 1993.
} 
escoceses e irlandeses se incorporaron en efecto a las filas libertadoras de 1816 a 1825. Nos parece a todas luces más pertinente insistir en lo que se ha denominado los "vagabundos de la República" o héroes republicanos desconocedores de los límites estatales y de las fronteras en un momento de creciente circulación de hombres e ideas. Esta contextualización muestra además que no se puede entender cabalmente el proceso de las independencias latinoamericanas sin situarlo en un contexto más amplio y de larga duración, desde el nacimiento de los Estados Unidos de América, de los avatares caribeños de la Revolución francesa y de las guerras internacionales que propició ${ }^{38}$.

No faltaron individuos aislados que fueron a buscar fortuna en el Nuevo Mundo, aprovechándose con sobrada habilidad de las circunstancias europeas. Cuando a Antonio Solar, de nación toscana, se le remitió a España en partida de registro por el Gobernador de Caracas, fue "a causa de haber colectado en aquella provincia y en la isla de Puerto Rico, donde se introdujo sin las legítimas licencias, diferentes limosnas" con el pretexto de rescatar a un hermano cautivo en Argel. Alegando no tener caudal alguno con que sustentarse, ni aun el "arbitrio de mendigar", había suplicado que a cambio del caudal embargado en Caracas, y mandado a España en virtud de varias Reales Cédulas (del 2 de julio de 1772 y 25 de agosto de 1780) se le socorriera por vía de limosna con la cantidad que le agradase al Consejo. Así consiguió 60 pesos y 15 reales de vellón que se sacaron "de los efectos de penas de Cámara". El cuento de Antonio Solar no carecía de veracidad: tras la captura de su hermano por los moros, "movido de la caridad se trasladó por las colonias francesas de Santo Domingo a la provincia de Venezuela", con una licencia que le hubieran otorgado los gobernadores Agüero y Unzaga para pedir limosna en la Capitanía General. Sólo la "competencia" que de semejante actividad se originó con los religiosos mercedarios de Caracas, tradicionalmente encargados de este aspecto de la "redención de cautivos" y de su obra pía -se "apoderaba de las limosnas"- dio origen a su arresto y luego a su remisión a España.

Ante semejante disyuntiva (piedad o ley), el gobernador quiso acatar el alegato del procurador de pobres del Consejo, José de Uruñuela, para actuar en consecuencia. Éste insistió en la voluntad del acusado de "redimir del cautiverio de los mahometanos a su hermano Pedro Solar, capitán de un barco de Sicilia", el hecho de que, encerrado en una cárcel pública sin poder "atender al recobro de sus ropas y vestidos que existían en Puerto Rico" padeció también el "quebranto" de haber sido conducido bajo partida de registro a España en el navío de San Carlos de la Compañía Guipuzcoana, hasta que una Real Orden le devolviese su libertad. Este caso dio origen

\footnotetext{
38 Mongey, Vanessa: «Les vagabonds de la république: les révolutionnaires européens aux Amériques, 1780 1820», en Morelli, Thibaud y Verdo: op. cit. (nota 25), pp. 67 y ss.; ThiBaud, Clément: Repúblicas en armas: los ejércitos bolivarianos en la Guerra de Independencia en Colombia y Venezuela, Bogotá, Instituto Francés de Estudios Andinos-Editorial Planeta, 2003, pp. 388-93; Brown, Matthew: Adventuring through Spanish Colonies: Simón Bolvvar, Foreign Mercenaries and the Birth of New Nations, Liverpool, University of Liverpool, 2006. Véase sobre el particular Irish Migration Studies in Latin America, Vol. 4, n. 2 (March 2006), y especialmente los artículos «Crusaders for Liberty or Vile Mercenaries? The Irish Legion in Colombia» (Matthew Brown) y «Rum, Recruitment and Revolution: Alcohol and the British and Irish Legions in Colombia's War for Independence, 1817-1823» (Karen Racine) http://www.irlandeses.org Langue, Frédérique: «La Independencia de Venezuela. Una historia mitificada y un paradigma heroico», Anuario de Estudios Americanos, vol. 66-2 (2009), pp. 245-276.
} 
a varias negociaciones acerca del manejo de las sumas embargadas, entre la Casa de Contratación de Cádiz, los padres redentores de Toscana, y el desconfiado representante de la orden en España. Ahora bien, y como puntualizó el defensor, quien insistió en que se le facilitara "lo conducente para vestirse y hacer el viaje a su país" así como los pasaportes necesarios "para que no sea nuevamente molestado":

...se le imposibilitaría su regreso a su país por la falta de medios y de los caudales que como suyos tiene entre los pertenecientes de su hermano que con ansia desea, por lo que padece el hambre y desnudez que puede presumirse de un extranjero que por vivir distante de su patria y sin algún conocimiento en estos países no tiene persona ni paraje alguno donde refugiarse (...). Molestado de tantas fatigas y persecuciones, desea el regreso al pueblo de su naturaleza ${ }^{39}$.

Muchos extranjeros afincados en Tierra Firme llegaron a solicitar una carta ya sea de "naturaleza" o bien de "tolerancia", aunque pertenecían o habían pertenecido a una nación enemiga. En 1784, Don Gabriel de Fageolles, natural de Francia, se presenta solicitando cédula de tolerancia. Como en muchos casos también, estos extranjeros merecedores del distintivo de "don" se señalan por sus "buenas circunstancias": en el caso de Gabriel de Cous y Fageolles, a quien las autoridades locales consideraron "acreedor a la Cédula de tolerancia para residir en estos dominios", "buena conducta, aplicación y habilidad en la agricultura", había contribuido "al aumento de la agricultura por medio de las mejores maquinas y buena dirección de labradores" y se dedicaba a "algunos ramos útiles, al comercio, principalmente a la fabrica del algodón, azúcar, añil y otros". Del interesado se sabe que se dedicaba además al comercio de mulas, a cuyo fin había solicitado anteriormente permiso ante el intendente José de Avalos para sacar mulas de la provincia para la del Guárico. El Intendente Saavedra, "a la mira de su conducta y operaciones" se mostró favorable a la expedición de una carta de tolerancia ${ }^{40}$.

En 1788, Don Pedro Lavie, también de nación francés y comerciante en la Guayana también solicita carta de naturaleza. Pero el caso quizás más representativo de estos inmigrantes de "buena fe" es el de Don Lázaro de Argain, natural de Alzuruco, en el obispado de Bayona (Francia). Al solicitar carta de naturaleza, indicó haber

39 AGI, Caracas, 279: informe firmado por D. Pedro Gallareta, tesorero receptor del Consejo. Madrid, octubre 1780. Incluye partida de 900 reales, Disposición del Consejo, Madrid, 12 de abril de 1782. Memorial de Fr. Francisco Moraleda, procurador general de la orden de la Merced diciendo que "los autos formados por el prior del convento de su orden en Caracas, sobre ciertas limosnas recaudadas por Antonio Solar son pretexto de ser para rescatar un hermano". El procurador de pobres, en sala primera del Consejo, 10 de noviembre de 1778. Decisión del Consejo, 9 de febrero de 1779. Impreso: en el convento de la "Real y Militar Orden de NS de las Mercedes, redención de cautivos, de esta villa de Madrid", 22 de junio de 1776, comparece ante el escribano el padre maestro general de la orden (tenía rango de Grande de España): las limosnas y negocios pertenecientes a la Obra Pía de Cautivos (redención de cautivos), testimonio en este sentido de Fr. Juan Cuevas y poder otorgado al efecto por Fr. Martín de Torres, Madrid, 28 de junio de 1776. El procurador de pobres, Joseph de Uruñuela, a la Corona; s.f. El Consejo mandó ponerlo en libertad el 28 de septiembre de 1778.

40 AGI, Caracas, 285: el Gobernador Capitán General y el Intendente remiten instancia de Don Gabriel de Cous y Fageolles, natural de Francia. Caracas, 20 de diciembre de 1785. Borrador de la Real Cédula, Madrid, 21de julio de 1786. AGI, Caracas, 283: Real Despacho a su favor, 22 de agosto de 1786 y oficio del intendente Saavedra, Caracas, 20 de octubre de 1786. Francisco de Saavedra a Don Antonio Ventura de Taranco, Caracas, 20 de octubre de 1786. 
"pasado de tierna edad a Caracas y hallarse casado en aquella ciudad con mujer blanca de origen española, con cinco hijos, y bienes raíces", acreditando los testimonios adjuntos su "honradez, fidelidad y amor a la Patria". De la memoria del fiscal se recuerda el servicio que "en todas ocasiones" le prestó al Rey, y no faltan certificaciones que apuntan a su "mera permanencia y continuación en esta ciudad" [Caracas] y "universal aceptación de todos los vecinos". "Hombre bien visto y honrado en sus procederes", y hasta "útill" a la Real Hacienda, el solicitante disponía de un "caudal suficiente". Casado con María de Jesús Blandain, vecina de la propia ciudad, persona blanca y de distinguida familia, disfrutaba de más de 12.000 pesos en fincas y bienes raíces, fundamentalmente casas de alquiler en Caracas aunque se dedicaba también a la siembra y cultura del añil, "en cuyo fruto ha logrado conveniencia". Se insiste asimismo en las "buenas prendas personales" de Don Lázaro así como en la "humanidad de las leyes" para con dichos naturales, y el hecho de que "no se muestran tan rígidas" cuando de su permanencia en las Indias se trata aunque no se expidió la carta de naturaleza por haber muerto el sujeto de acuerdo con una nota del expediente. Este también incluyó certificación de Martín de Tovar, conde de Tovar, José Antonio Pacheco, conde de S. Javier y unos cuantos mantuanos más ${ }^{41}$.

En 1784, Don Santiago Luis de la Mosca y Acosta, vecino de Nueva Barcelona, en la Provincia de Cumaná, entrega una solicitud al efecto, argumentando lo siguiente: natural de la ciudad de Gante en los Estados de Flandes, se embarcó en 1730 para América en

uno de los barcos de la Real Compañía Guipuzcoana y habiendo llegado a la ciudad de Caracas, pasó en el mismo año a la de Nueva Barcelona, donde se estableció, y ha permanecido, hasta el presente por el dilatado espacio de 54 años corridos desde su arribo a aquellos dominios.

Se dedicó además al "honroso ejercicio de labrador, granjeándose la estimación y aprecio de aquellos vecinos, y adquiriendo con su aplicación y conducta un decente caudal, que le ha producido la labranza y fomentado la cría de ganados a que posteriormente se aplicó, retirado en los llanos de dicha jurisdicción". Contrajo matrimonio con doña Juana Álvarez del Bastardo, de las principales familias de Nueva Barcelona, y luego de la muerte de ésta, con su sobrina carnal, que llevaba el mismo nombre y apellido. En la información judicial que presentó al teniente de justicia mayor y comandante de las armas de la ciudad de Nueva Barcelona, y que incluye cinco testimonios de vecinos honrados, insiste en el hecho de que, desde que arribó a estas costas

....ha considerado por principal objeto de su obligación el dedicarse al servicio del público, y estar pronto para acudir al servicio de V.M. como lo ha hecho en cuantas ocasiones se han ofrecido. Y este desempeño de su deber con la honrada conducta que

\footnotetext{
${ }^{41}$ AGI, Caracas, 364: "Índice alfabético de los expedientes del negociado de Caracas desde 1760 a 180 ...”; AGI, Caracas, 282: José de Gálvez, San Lorenzo, 16 de noviembre de 1784, a Antonio Ventura de Taranco (dentro de la instancia promovida por Don Lázaro de Argain). Solicitud de Real Gracia de Don Lázaro de Argaín, Madrid, 24 de diciembre de 1785 y acuerdo de la Cámara de Indias, 31 de enero de 1785.
} 
siempre ha observado, no sólo le han conciliado una general estimación, sino que le han hecho acreedor a que se pusiesen a su cargo los empleos honoríficos de Alcalde ordinario, de la Santa Hermandad, y regidor que ha obtenido en la villa de Aragua de aquella jurisdicción, acreditando su desempeño y arreglado proceder con la declaración de buen ministro y digno de las honras de V.M. que se le ha hecho en las respectivas residencias ${ }^{42}$.

Estos ejemplos no carecen de interés en la medida en que las situaciones registradas antes de 1810 incidieron sobremanera en el estatuto que se les concedió a los extranjeros en la Venezuela republicana. Hay que señalar al respecto que, de acuerdo con la Constitución de 1830, la nacionalidad venezolana puede adquirirse a partir de esa fecha por nacimiento o por naturalización. En este renglón figuran dos categorías: si bien "los nacidos en el territorio de Venezuela que el 19 de abril de 1810 estaban domiciliados en cualquier punto de él y hayan permanecido fieles a la causa de la Independencia" son los primeros en valerse de esta disposición, también se benefician los extranjeros que lucharon en la guerra de Independencia ${ }^{43}$.

El rastreo de fuentes a través de las cartas de naturaleza, arroja resultados a veces muy alejados del espíritu revolucionario que se les achaca a los sujetos de determinadas naciones. Una vertiente peculiar, la de los médicos y curanderos en la Provincia de Caracas, permite a la vez ilustrar esta problemática y relativizarla al puntualizar la "integración" de determinadas naciones (franceses, portugueses, italianos) gracias a su profesión y manifiesta "utilidad al Estado". Fueron numerosos los médicos extranjeros, sobre todo franceses, con o sin carta de naturalización (o de tolerancia, paso previo o compensatorio según los casos), en la Provincia de Caracas hasta bien consumada la Revolución de Independencia. Y otro tanto se señaló en el caso de Nueva Granada, después de la capitulación de los Comuneros (1782) y pese al seguimiento que las élites locales le hicieron a la coyuntura europea y especialmente a la invasión de la Península por Napoleón.

El caso del médico francés Luis Francisco de Rieux, perseguido y encarcelado por su continua comunicación con Antonio Nariño, ascendido a coronel por éste y miembro de la junta cartagenera que se opuso a Bolívar (1815), encargado más adelante de la defensa de Barranquilla y luego de la misma Cartagena, es realmente excepcional: prosiguió en efecto su larga carrera política eludiendo el fracaso de la Gran Colombia, como gobernador de Santa Marta, senador de la República, Intendente del Zulia, ministro de guerra en la administración de Joaquín Mosquera, diputado a la Asamblea Constituyente de 1831 y Senador de la República $\left(1836,1837\right.$ y 1838) ${ }^{44}$.

\footnotetext{
42 AGI, Caracas, 279: solicitud de carta de naturaleza de Don Santiago Luis de la Mosca y Acosta, vecino de Nueva Barcelona, Provincia de Cumaná, en virtud de poder (Santiago Sáenz), Madrid, 18 de febrero de 1784; Real Cédula correspondiente fechada en Aranjuez, 23 de junio de 1784.

43 Cf. Constitución de 1830, art. 5 y 11, en Brewer CARÍAs, Allan: Las Constituciones de Venezuela: Estudio preliminar y textos constitucionales de 1810 a 1864, Caracas, Academia de Ciencias Políticas y Sociales, 2008.

44 Langue, Frédérique: «La blancura del color quebrado. Curiosos y curanderos en la Caracas del orden ilustrado», en Bernabéu, Salvador y Varela, Consuelo (coords.): La ciudad americana, mitos, espacios y control social, Madrid, Ediciones Doce Calles, 2010, pp. 229-253. GARcía EstradA, Rodrigo: «Los extranjeros y su participación en el primer período de la Independencia en la Nueva Granada 1808-1816», Historia Caribe, 16 (2010), pp. 6062 (disponible en: http://redalyc.uaemex.mx/src/inicio/ArtPdfRed.jsp?iCve=937170330). También menciona otros
} 
Para 1790 Don Bartolomé Dousour, médico de los Reales hospitales, profesor de medicina y cirugía en Caracas, solicitó carta de naturaleza (se le dio carta de tolerancia). Parece ser que los médicos franceses, herboristas, curanderos y cirujanos fueron especialmente numerosos en la Provincia de Venezuela. En Cumaná, se dieron los casos en los años 60 del médico francés Francisco Cabrillac de Fontaines, casado tras unas cuantas peripecias (más precisamente burlando la oposición paternal) con la cumanesa María del Rosario García de Urbaneja; en la década siguiente, del practicante Juan Buscat, cuyos títulos sin embargo nunca fueron confirmados o concedidos por el Protomedicato, pero que encontramos para 1810 respaldando la causa independentista y envenenando al jefe español Gorrín en 1815, a quien fingía curar ${ }^{45}$.

\section{LA HISTORIA ATLÁNTICA Y LOS EXTRANJEROS: A MODO DE CON- CLUSIÓN}

Los últimos aportes de la historia atlántica tienen a demostrar la pertinencia del desliz conceptual a la hora de interpretar la actuación y las prácticas de determinados actores tanto en lo económico como en lo social. De ahí el interés que hay en trascender la categoría histórica de nación para pasar a la de "transnación" tal como la utiliza Ana Crespo Solana. Quizás sea en efecto la conceptualización más adecuada al caso de estas microsociedades, cuando no redes de individuos conectados y comunidades no menos relacionadas entre $\mathrm{si}^{46}$, habida cuenta de la colaboración que se pueda dar entre las distintas comunidades (caso de las comunidades mercantiles "extranjeras"). Recuerda asimismo que "desde el punto de vista socio-mental e institucional, los componentes de estos grupos se habían acogido a un fuero de extranjería, que les otorgaba un status complejo en el contexto de una sociedad de antiguo régimen, $\mathrm{y}$ que hasta cierto punto estaban condicionados, dichos privilegios, por las relaciones políticas que se habían dado entre las naciones de expulsión y de acogida".

En este sentido, las sobrevaloradas manifestaciones de tipo emocional, de "miedo a la revolución" o de angustia generada por las referencias a las rebeliones esclavas, por más que subsistan en el imaginario del siglo XIX (de las élites blancas como fue el caso en Cuba) o que se borren al contrario de la memoria de los actores de la Independencia a favor de otras consideraciones (caso de Venezuela, donde las clasificaciones raciales, pese a la numerosa presencia de afrodescendientes no se compaginaron para nada con opciones políticas claras pese a las similitudes registradas con el caso haitiano, en términos de violencias raciales y de intensidad de los enfrentamientos), no dejan de insertarse en una temporalidad de larga duración así como en estrategias de control social ideadas por los gobiernos de turno. En este sentido,

casos de franceses emigrados aunque de formación militar.

${ }_{45}$ AGI, Caracas, 364: "Índice alfabético de los expedientes del negociado de Caracas desde 1760 a $180 \ldots$..." Aмодio, Emanuele: «Las calenturas criollas. Médicos y curanderos en Cumaná durante el siglo XVIII», Procesos históricos, 1 (2002): http://www.saber.ula.ve/handle/123456789/23077

${ }^{46}$ Crespo Solana, Ana: «Comunidad y familia versus nación. Cooperación y competencia en las redes de comerciantes neerlandeses (1690-1730)», en CRESPo Solana (coord.): Comunidades transnacionales: colonias de mercaderes extranjeros en el Mundo Atlántico (1500-1800), Madrid, Ediciones Doce Calles, 2010, p. 55. 
los imaginarios forjados a raíz de los sucesos de Haití y de sublevaciones locales se diluyeron en una "representación semántica común, no sólo a los blancos de las sociedades esclavistas americanas, sino también en casi todo el mundo atlántico" y no solamente en el espacio hispano ${ }^{47}$.

Otro punto escasamente traído a colación cuando se relacionan presencia extranjera y procesos revolucionarios en América, es la construcción identitaria y política que subyace en las categorías de vecindad y naturaleza heredadas de la Península, así como la ausencia de oposición entre ambos términos. Este fenómeno aparece a todas luces en el proceso de naturalización de extranjeros, en que las clasificaciones sociales tienden a primar sobre definiciones legales. Además, en el contexto de las "revoluciones atlánticas" y especialmente de la Revolución francesa, el tema de la ciudadanía llegó a cobrar una vigencia insospechada. Recordemos en efecto que un decreto de 1792 iguala a los libres de color con los blancos, de ahí la vigencia del tema en territorios de ultramar, por lo menos en el caso de la Capitanía General de Venezuela.

Es por lo tanto el tema de la igualdad legal, anhelada por la "pardocracia" (término forjado por el Libertador Simón Bolívar) o sea por los pardos aventajados y "beneméritos", dicho de otra forma por la "élite de color" (un $40 \%$ de la población como mínimo) pronta además en alistarse en las milicias urbanas y en blanquearse para acceder a ciertos oficios - una limpieza de color que sigue el modelo discursivo, simbólico y social de la limpieza de sangre como hemos tenido la oportunidad de comprobarlo en estudios anteriores-, el que asoma verdaderamente a través de la presencia extranjera (hombres e ideas) en el Caribe, tanto en la costa venezolana como en el Caribe colombiano (región de Cartagena) y mucho más allá entonces de las omnipresentes aunque vagas referencias emocionales a Haitín ${ }^{48}$.

La cambiante combinación de imperativos económicos y de ideas novedosas, la permanencia de las mismas en el ámbito del caribe hispánico junto a la difusión de imaginarios políticos de nuevo cuño, puede resumirse en las palabras de Eric Van Young: no hay que confundir transacciones con redes sociales ${ }^{49}$. Las comunidades establecidas por los migrantes en el espacio caribeño traspasan en realidad las fronteras fijadas por los imperios, en una suerte de "comunidad imaginada" que se expresa a todas luces en los ejércitos libertadores así como en la circulación ejemplar de ciertos individuos, combatientes de la libertad o propagandistas de una nueva ciudadanía

47 Gómez Pernía: op. cit. (nota 29), pp. 475 y ss.

48 Herzog, Tamar: Defining Nations. Inmigrants and Citizens in Early Modern Spain and Spanish America, Yale University Press, 2003, pp. 205-7. Langue, Frédérique: «La pardocratie ou l'itineraire d'une 'classe dangereuse' dans le Venezuela des XVIIIe et XIXe siècles», Caravelle, LXII (1997), p. 65 (disponible en Nuevo Mundo, Mundos Nuevos: http://nuevomundo.revues.org/643). GómEZ, Alejandro E.: «Las revoluciones blanqueadoras: elites mulatas haitianas y "pardos beneméritos" venezolanos, y su aspiración a la igualdad, 1789-1812», Nuevo Mundo Mundos Nuevos, 5 (2005); del mismo autor: «¿Ciudadanos de color?», Nuevo Mundo, Mundos Nuevos, BAC-Biblioteca de Autores del Centro, 2007: http://nuevomundo.revues.org/9973 y «La Revolución de Caracas desde abajo», Nuevo Mundo, Mundos Nuevos, 8 (2008): http://nuevomundo.revues.org/32982 LAsso, Marixa: «El día de la independencia: una revisión necesaria», Nuevo Mundo, Mundos Nuevos, 8 (2008): http://nuevomundo.revues.org/32872; y de la misma autora, «Race, War and Nation in Carribean Gran Colombia, Cartagena, 1810-1832», The American Historical Review, vol.111-2 (2006), pp. 336-361.

49 VAn Young, Eric: «Social Networks: A Final Comment», en Bottcher, Hausberger e Ibarra (eds.): op. cit. (nota 11), p. 301. 
fundada en la libertad y la igualdad de derechos, circulación que se evidencia aún más a partir de la década de 1810. En esta vertiente de las relaciones de los metropolitanos y más todavía de los criollos quizás radique la mayor expresión de las relaciones con los variopintos extranjeros que recorrieron la cuenca caribeña a finales del siglo XVIII y que en su gran mayoría fueron partícipes de acontecimientos de cuño metropolitano, apoyándose sin embargo en incluso individuos o núcleos familiares radicados en América más que en redes sociales -salvo contadas excepciones- de encumbrada efectividad. Prueba además de este fenómeno todavía por indagar e investigar son incluso esas transacciones en lo militar y financiero, tanto a nivel de las naciones como de sus representantes o "naturales", dicho de otra forma las "ayudas" recíprocas consentidas en el sobresaltado contexto del proceso de emancipación y más adelante de las Independencias americanas por las mismas naciones presentes en el Caribe hispano: tal fue el caso cuando el gobierno por ejemplo de la isla de Guadalupe solicita un "socorro pecuniario" (1802) y a la inversa, cuando el Gobierno francés de la isla de Martinica les presta 4.600 francos a los emigrados de Tierra Firme. Para 1822, los imperios siguen negociando en ese aspecto: el Ministro plenipotenciario de Francia en Madrid los reclama en efecto, en vano ya que se recomienda, al igual que Francia en situaciones similares, "dejar dormir el negocio" 50.

50 AGI, Caracas, 55: el Consejo de Estado a Gobernación de Ultramar, Madrid, 2 de marzo de 1822; AGI, Caracas, 60: el Capitán General al Ministro de Hacienda, Caracas, 1 de diciembre de 1802. Sobre las "comunidades imaginadas", nos remitimos a ANDERSON, Benedict: L'imaginaire nacional. Réflexions sur l'origine et l'essor du nationalisme, París, La Découverte, 2002 (ed. inglesa: Imagined Communities: Reflections on the Origin and Spread of Nationalism, Londres, Ed. Verso, 1983). 